The private schooling phenomenon in India: A review

Geeta Gandhi Kingdon

Department of Quantitative Social Science Working Paper No. 17-06

April 2017 


\section{Disclaimer}

Any opinions expressed here are those of the author(s) and not those of the UCL Institute of Education. Research published in this series may include views on policy, but the institute itself takes no institutional policy positions.

DoQSS Workings Papers often represent preliminary work and are circulated to encourage discussion. Citation of such a paper should account for its provisional character. A revised version may be available directly from the author.

Department of Quantitative Social Science, UCL Institute of Education, University College London, 20 Bedford Way, London WC1H 0AL, UK 


\title{
The private schooling phenomenon in India: A review
}

\author{
Geeta Gandhi Kingdon ${ }^{1}$
}

\section{$\underline{\text { Abstract }}$}

This paper examines the size, growth, salaries, per-pupil-costs, pupil achievement levels and cost-effectiveness of private schools, and compares these with the government school sector. Official data show a steep growth of private schooling and a corresponding rapid shrinkage in the size of the government school sector in India, suggesting parental abandonment of government schools. Data show that a very large majority of private schools in most states are 'low-fee' when judged in relation to: state per capita income, perpupil expenditure in the government schools, and the officially-stipulated rural minimum wage rate for daily-wage-labour. This suggests that affordability is an important factor behind the migration towards and growth of private schools. The main reason for the very low fee levels in private schools is their lower teacher salaries, which the data show to be a small fraction of the salaries paid in government schools; this is possible because private schools pay the market-clearing wage, which is depressed by a large supply of unemployed graduates in the country, whereas government schools pay bureaucratically determined minimum-wages. Private schools' substantially lower per-student-cost combined with their students' modestly higher learning achievement levels, means that they are significantly more cost-effective than government schools. The paper shows how education policies relating to private schools are harmful when formulated without seeking the evidence.

Keywords: Private schooling; learning achievement; value for money; India

Contact Details: Geeta Gandhi Kingdon (g.kingdon@ucl.ac.uk) UCL Institute of Education

Acknowledgements: The author gratefully acknowledges the research assistance of Prashant Verma with the statistical analysis of NSS and DISE data. Any errors are the author's.

\footnotetext{
${ }^{1}$ UCL Institute of Education
} 


\section{Introduction}

Private fee charging schools are a visibly ubiquitous phenomenon in urban and rural India. On the one hand they are in high public demand and growing in numbers, on the other, in public discourse their growth is often dubbed the 'mushrooming of teaching shops' and opposed. State governments regulate private schools to a lesser or greater degree. The Right to Education Act 2009 co-opts them for the delivery of education, mandating that they give at least $25 \%$ of their seats to children of 'economically weaker sections and disadvantaged groups' for which the state governments will reimburse them, thus setting up a unique kind of public-private partnership in education.

Yet, despite their preponderance and growth, and the public expectation from them, relatively little is known about the nature of private schools in the country. This review unravels the enigma by presenting up-to-date evidence on several important facets of private schools, and benchmarks these by comparing with government schools.

The paper asks a number of questions: Policy makers' perceptions about private schools are more heavily shaped by the types of private schools that are prominent and visible in the national and state capitals, but are these schools representative of the wider reality of private schooling in the country? What are the actual numbers of private schools, and just how rapidly are they growing? How diverse are they in terms of their fee levels and costs, and are high-fee private schools the main bulk or just a small minority - of all private schools? What are their teacher salaries, the achievement levels of their students, and the 'value for money' they offer? What are the implications of the RTE Act for the existence and spread of private schools? Given the omnipresence of private schools in India, these are important questions, and it is not possible to make sensible education policies in ignorance of the reality of private schooling in the country.

This paper offers evidence on these issues from the official District Education System on Education (DISE) data, National Sample Survey (NSS) household data, the Annual Status of Education Report (ASER) data, and from data presented in a number of existing studies.

Section 2 describes the datasets used, and assesses their strengths and drawbacks. Section 3 examines the size and recent growth of the private and government schooling sectors in India. Section 4 presents evidence on the fee levels of private schools by state. Section 5 presents data on teacher salaries in private and government schools while Section 6 examines the learning outcomes in these two school sectors. Section 7 compares the cost-effectiveness of private and government schools, assessing whether private schools offer higher value-for-money to parents than that which the tax-payer gets from public expenditure on education. Section 8 considers the provisions of the Right to Education Act that impinge on private schools and the last Section concludes.

\section{The data}


There are several challenges in piecing together the picture on private unaided schooling in India to answer the above questions, since there is no one comprehensive data source on private schooling in India. Before the passage of the Right to Education (RTE) Act 2009, in most states private schools were not even required to be registered let alone be mandatorily government-'recognised'. While officials thus do not have a comprehensive list of all unrecognised private schools, they do informally know of many of these schools, since they are required to serve closure notices to the unrecognised schools. Yet, the official District information System on Education (DISE), which is meant to be an annual census of all schools in the country, generally does not collect data from most of the so-called nonrecognised private schools ${ }^{2}$. Moreover, coverage of even the recognised private schools is incomplete in DISE since not all private unaided schools give their data. Finally, to compound matters, although the DISE questionnaire separately identifies aided and unaided private schools, in the DISE data report cards published annually by the official agency ${ }^{3}$, in practice unfortunately these two types of schools are often lumped together and treated as a single category 'private schools'.

While the Annual Status of Education Report (ASER) published by NGO Pratham is helpful in generating extensive evidence on private as well as public schools across about 15,000 villages across all Indian districts annually, it is based on a rural survey only and misses out urban India altogether. Moreover, it also lumps together private aided and private unaided schools into a single category 'private'. While for some states, the distinction is unimportant because there are few aided private schools there, in other states with a higher proportion of aided private schools, the distinction matters much.

Despite sharing the word 'private' in their names, private unaided and private aided schools differ fundamentally in their modes of operation. Private aided schools are virtually like public schools in the way they are governed. Although nominally and de jure run by their private management boards, de facto they are heavily governed by the state. Following centralising legislation in the early 1970s which virtually nationalised the aided schools ${ }^{4}$, their teachers' salaries are paid by the government treasury and not via the private school management; they are paid at the same rate as government school teachers; and their salaries are paid directly into the bank accounts of their teachers, exactly as in government schools. Moreover, private aided schools' teachers are recruited and appointed not by their respective managements but by a government-appointed state Education Service Commission, the same body that recruits and appoints teachers to the government schools. All this implies that after the early 1970s, aided schools became virtually like government schools, where teachers are roughly only as accountable to their

\footnotetext{
2 'Recognition' is a government stamp of approval for a private school, to certify that it is fit to run as a school. Since the enactment of the Right to Education Act 2009, all private schools have to legally be recognised. The Act stipulates the conditions a private school has to fulfil in order to be 'recognised' and it allows state governments to add further recognition conditions. Although the state governments are clamping down on unrecognised private schools, surveys suggest that their numbers continue to be substantial.

${ }^{3}$ The agency that collates the DISE data nationally from all the states is the National University of Educational Planning and Administration, NUEPA, in New Delhi. The inconsistencies in DISE data have often been highlighted (for one example, see NUEPA study by Ramachandran, 2015).

${ }^{4}$ Following extensive teacher union protests by the teachers of aided private schools, sit-ins, strikes and examboycotts over a period of months in Uttar Pradesh, the Salary Disbursement Act 1971 was passed by the state Legislative Assembly; similar Acts were passed in other states, e.g. the Direct Payment Act of Kerala in 1972.
} 
respective private managements as government school teachers are to district education authorities. Furthermore, aided private cannot charge any tuition fee in elementary education (upto grade 8), just as government schools cannot.

By contrast, private unaided schools conform to the stereotypical idea of what private schools are, namely autonomous fee charging schools run by private managements and which recruit/appoint their own teachers and pay them salary scales determined by themselves (roughly based on the supply and demand of educated persons in their local labour market), rather than necessarily following the government pay structure. Thus, we shall refer to private aided schools simply as Aided schools, and shall refer to private unaided schools simply as Private schools. Thus, for the purposes of this paper, all Indian schools are categorised into three major types: Government schools (whether run by state, central or local government), Aided schools and Private schools.

The National Sample Survey (NSS) which is an annual household survey, periodically collects information on education, for example, in 1995-96, 2007-08 and again in 2014-15. While NSS is a household survey and not a school survey, it nevertheless has valuable information on enrolment in different school types, which permits cross-checking the veracity and comprehensiveness of school censuses (such as DISE) and surveys (such as ASER), and it also furnishes data on household expenditure on education in different types of school - government, aided, and private 5 .

This paper draws together evidence from all the above sources, i.e., raw National Sample Survey (NSS) data for various years (latest being 2014-15, $71^{\text {st }}$ Round NSS), the ASER data, District Information System on Education (DISE) data, and data in studies carried out by individual scholars or institutions.

\section{The size and growth of the private schooling sector in India}

A useful starting point is to first establish the extent of private schooling in the country, and to see its growth over time. We present some data on this. But before doing that, it is useful to consider the definition of 'private schools' in official DISE data.

Published DISE tables typically divide all schools into two types: 'government' and 'private' schools. They inadvertently misestimate the extent of private schooling, for three reasons:

1. DISE fails to cover all of the so-called 'unrecognised' private unaided schools, leading to an under-estimation in the true size of the private school sector.

\footnotetext{
${ }^{5}$ One caveat with NSS data is that when householders fill this survey, some may not know whether the school their child attends is private aided or unaided, since this distinction is not clear since: all aided schools start life as unaided and later some of them apply for and get government grant-in-aid, and some parents may not know about this change; many aided schools run unaided primary sections and run aided upper primary (middle/junior) sections and parents may be unaware of this change when their child moves from primary to upper primary; although aided schools are not meant to charge any tuition fee, de facto they charge fee under other heads, but the parent may not know this distinction - knowing only that she has to pay a given amount.
} 
2. In its published tables, DISE does not add even the few unrecognised private schools that it does collect data on, again leading to an underestimation of the private sector.

3. DISE lumps together aided and private unaided schools into a single category 'private', leading to an over-estimation of the true size of the private school sector.

Of these three sources of bias, the third leads to a relatively minor over-estimation, but the first two sources lead to a substantial under-estimation, of the size of the private schooling sector in India, and we turn to show this below.

\section{Failure to comprehensively cover the unrecognised private schools}

As stated in the Introduction, DISE does not cover all the un-recognised private schools. Kingdon (2007) reported the findings of five studies from different parts of India to show that there were roughly as many unrecognised private schools in India as there were recognised ones ${ }^{6}$ and there continue to be journalistic reports of large numbers of unrecognised schools. In other words, DISE reportage of private schools appears to be greatly under-estimated.

While the RTE Act 2009 mandated that no school can run without obtaining a certificate of government recognition, thousands such schools nevertheless continue to function. District education authorities routinely give warning notices to unrecognised schools each year, threatening to close them down, which suggests they are well aware of many unrecognised schools, and yet DISE data report zero unrecognised schools in many states, as seen in Table 3, e.g. Chhattisgarh, Gujarat, Himachal, Jharkhand, Karnataka, Maharashtra, Rajasthan and Uttar Pradesh, thus missing out at least tens of thousands of unrecognised private schools ${ }^{7}$. In summary, DISE seriously under-estimates the extent of private schooling in the country because of its failure to comprehensively cover the unrecognised private schools.

Failure to include even the unrecognised private schools on which data is collected While DISE collects information on a few unrecognised private schools in many states, and Table 3 (calculated by the author from raw DISE data), shows that such included schools constituted $2 \%$ of all elementary schools in the country in 2014-15, many DISE tables published by NUEPA exclude these schools from the 'private schools' category. This leads to another small under-estimation of the true extent of private schooling in the country.

\footnotetext{
${ }^{6}$ Muralidharan and Kremer (2006) find that in their national survey of 20 states, $51 \%$ of all private rural primary schools were unrecognized. This accords with evidence from individual states in other studies which find that between 41 and 86 percent of all primary private schools were unrecognized in different parts of India: Aggarwal (2000) found that in his four surveyed districts of Haryana in 1999, there were 2120 private primary schools of which $41 \%$ were unrecognized. The PROBE survey of 1996 in 5 north Indian states did a complete census of all schools in 188 sample villages. It found 41 private schools, of which $63 \%$ were unrecognized. Mehta (2005) found that in 7 districts of Punjab, there were 3058 private elementary (primary +junior) schools, of which $86 \%$ were unrecognized. For more evidence based on various data sources, see Kingdon (2006).

${ }^{7}$ A newspaper report in June 2016, included here as Annex 1, shows the local teacher union alleging that there are at least 2000 unrecognised private schools in one district (Lucknow) of Uttar Pradesh but the DISE District Report Card 2014-15 shows 0 unrecognised private schools and 2840 recognised private schools in this district. There are 75 districts in UP and DISE reports a total of 78,094 recognised private schools in UP. Thus, if the same ratio of recognised to unrecognised schools exists in the whole UP as in Lucknow district, then there would be an estimated 54,996 unrecognised private elementary schools in Uttar Pradesh alone!
} 


\section{Lumping together aided and private schools}

As mentioned above in the Introduction, aided schools are private virtually only in name, since their pupil fee levels and teacher salaries and emoluments are the same as in government schools, and since their teachers are paid directly by the government, and are recruited and appointed by the same body and via the same process as government school teachers. The only role of the private management is that they originally provided the land/buildings in which the school runs and, in consideration of that, the monthly salary sheet of the aided school teachers is counter-signed by their private management before salaries are transferred by the government treasury into the teachers' bank accounts. This minor role plus the fact that aided school teachers cannot be transferred to other schools (whereas government school teachers can), is used to maintain the veneer that these schools belong to their private managements, and in most of the tables presented in the DISE data reports, the term 'Private' school includes both aided and private schools. The separate classification of these two school types - aided and private - and separate presentation of data on them, is an important issue that needs serious thought by policy makers.

In summary, published DISE data over-estimates the extent of private schooling in the country by including aided schools in the category of 'private schools', but seriously underestimates the extent of private schooling by excluding the unrecognised private schools. The impact of the RTE Act 2009 on the number of unrecognised private schools is unclear as yet, and is a subject for new research.

For the purposes of this paper, and in contrast with DISE data, we use the term 'private school' to include private unaided schools (both recognised and unrecognised) as these display the conventional defining features of 'private', i.e. schools that have autonomy in teacher recruitment and job-separation and in fixing teacher salary and pupil fee levels, and our definition of 'private' excludes aided schools. Where we present data on government (public) schools, aided schools are again not taken into account, even though they are publicly funded and controlled.

\section{Extent of private schooling (in 2014-15)}

What proportion of the elementary age children are actually studying in private schools in the different states of India? Table 1 shows the pattern of private school attendance in India. Firstly, private schooling is much more spread in urban than in rural areas. Secondly, the utilisation of private schooling is perverse from an equity point of view because (except in rural areas in the secondary age) private schooling is most prevalent at the primary school stage, less prevalent at the upper primary stage, and the least prevalent than at the secondary/higher-secondary school stage.

Table 1 shows that in 2014-15, in the primary school age group (6-10 year olds), $49 \%$ of urban and $21 \%$ of rural children attended private schools. That nearly half of all primary age children in urban India are studying in private schools is striking. In the upper primary school age group (11-14 year olds), a rather smaller proportion are attending private unaided schools: $40.7 \%$ in urban and $17.5 \%$ in rural India. This is perverse from an equity point of view because it implies that many children who were willing and able to pay for their primary education (by attending private schools) end up going to free government or aided schools for their upper primary education. 
In urban areas, at the secondary school stage, the proportion attending private schools shrinks further still, to $36 \%$ - compared with $49 \%$ at the primary and $41 \%$ at the upper primary stage.

Apart from this wide rural-urban disparity, there are also pronounced inter-state variations in the extent of utilisation of private schooling, as seen in Table 2. States with high prevalence of private schooling are Andhra, Haryana, Punjab, Rajasthan, Telengana and Uttar Pradesh.

\section{Change in private schooling, over time}

How has the extent of private schooling changed over time? Table 4 shows the temporal change in number of government and private schools, and Table 5 shows the change in their enrolments, based on the author's analysis of raw DISE data on 20 major states of India. Table 4 shows that, over the four year period 2010-11 to 2014-15, the total stock of government schools in India (20 major states of India) rose by a mere 16,376 govt. schools. By contrast the number of private schools rose by 71,360 schools. Despite the modest increase in the number of govt. schools, the total enrolment in govt. schools over this period actually fell by 11.1 million (1 crore 11 lakh) students, whereas total enrolment in private schools rose by 16 million (1 crore 60 lakh) students, over the same 4 year period.

In some states, the growth of private schooling was very pronounced, e.g. in Tables 4 and 5 in Uttar Pradesh, the number of private schools rose by 31,196 over this short four-year period, and private school enrolment rose by nearly 7 million (70 lakh) students and govt. school enrolment fell by 2.6 million ( 26 lakh) students, over this four-year period.

Another way of gauging the demand for private and government schools is to observe how the average size of schools has changed over time. Table 5 shows that the average size of govt. elementary schools in India fell from 122 students per school in 2010-11 to 109 students per school by 2014-15, a decline of 12 students per govt. school, or a decline of about $10 \%$ over a short four year period. In some states, the average size of govt. schools fell steeply, e.g. in Maharashtra, UP, etc. By contrast, the average size of private schools was significantly larger in the baseline year (202 instead of 122), and it also further rose from 202 to 207 in the four year period between 2011 and 2015, even though the number (supply) of private schools also rose strongly over the period by around 70,000 new private schools.

Table 5 also shows the picture for each state. In Madhya Pradesh, mean govt. school size fell from an already low of 95 students in 2010 to only 70 students in 2015 , reduction of $26.3 \%$ in mean govt. school size in just 4 years. While it is expected that average school size in the hilly states would be lower, the very low average enrolment per govt. school of 49 in Himachal, 54 in Uttarakhand and 55 in Jammu-Kashmir in 2010 fell further to 38,44 and 43 respectively, by 2015 . An average size of 38 students per govt. school means less than 8 students per class (for primary schools with classes 1 to 5 ) or less than 5 students per class (for elementary schools, with classes 1 to 8 ). Thus, the govt. schools in these three hilly states are both pedagogically and economically unviable. Other states which saw a 
heavy reduction in govt. school enrolments and thus in the mean govt. school size are Uttar Pradesh, West Bengal, Maharashtra and Haryana. In several large states, by 2015-16, the mean number of pupils in govt. schools fell to significantly below 100, e.g. Madhya Pradesh (70), Andhra (73), Chattisgarh (74), Assam (83), Odisha (86) Maharashtra (88), Karnataka (89), Rajasthan (89), again pointing to both pedagogical and economic unviability.

The abandonment of govt. schools and the shift towards private schools is also clearly visible when we examine how the number of govt. schools that are 'small' or 'tiny' has increased over time.

\section{Abandonment of government schools, migration to private schools}

We define a 'small' school as one in which total enrolment (in the school as a whole) is 50 or fewer students, which means 10 or fewer students per class, in a primary school, or it means 6 or fewer students per class, in an elementary school. We define a 'tiny' school as one in which total enrolment is 20 or fewer students, which means 4 or fewer students per class, in a primary school or say 3 students per class in an elementary school ${ }^{8}$.

Table 6 illustrates the phenomenon of the abandonment and emptying of govt. schools by highlighting its manifestation in the rapid growth of 'small' and 'tiny' government schools in India.

We can measure the emptying of government schools further by examining the small-school phenomenon, and asking whether the number of govt. schools that are small or tiny is growing over time. Table 6 shows that in the year 2010-11, India (20 major states) had $3,13,169$ small govt. schools, which constituted $30.2 \%$ of all govt. schools. By 2014-15, the number of small govt. schools had increased $3,86,328$ (36.7\% of all govt. schools), and by the following year 2015-16, their number had rather sharply further increased to $4,18,825$ small schools $(40.0 \%$ of all govt. schools). In other words, small govt. schools increased from $30 \%$ to $40 \%$ of all govt. schools, signifying a rapid emptying of govt. schools in a short period. Correspondingly, the average number of pupils per small govt. school fell from 30.4 pupils in 2010 to 28 pupils in 2015. Pupil teacher ratio also fell from 15 to 12.7 between 2011 and 2015. The government's teacher salary per-pupil-expenditure increased from Rs. 1887 per pupil per month in 2010 to 3090 pppm in 2014 and further to 3430 pppm in 2015.

What has happened to the number of govt. schools that are 'tiny' i.e. with a total enrolment of 20 or fewer students? Here too the number of such tiny govt. schools has increased over time, from 71,189 tiny govt. schools in 2010, to 100,409 tiny govt. schools in 2014, and further to 108,183 tiny govt schools in 2015 . The average teacher-salary-cost-per-pupil in these tiny government schools rose from being around Rs. 4250 per pupil per month in 2010 to 6522 pppm in 2015.

\footnotetext{
${ }^{8}$ If a school has both primary and middle sections in it, i.e. has 8 grades in it (class 1 to 5 being the primary grades and class 6 to 8 being the middle/junior grades), then the number of students per class will be even lower.
} 
Older DISE data for 2005-06 shows that there were 60,033 tiny govt. schools (with $<=20$ pupils) and $2.31,989$ small govt. schools (with $<=50$ pupils) in the same 20 major states, indicating that the emptying and decline of govt. schools is a long term trend.

Table 7 shows the emptying govt. schools phenomenon by state, for the period 2010 to 2015. Madhya Pradesh, Rajasthan, West Bengal and Andhra Pradesh have had the greatest emptying of govt. schools, in terms of highest absolute increases in the number of tiny govt. schools. Madhya Pradesh and Maharashtra saw an increase of nearly 24,000 and nearly 22,000 in the number of 'small' govt. schools, and West Bengal and Uttar Pradesh also saw large increases. The emptying of govt. schools and the resultant swelling number of govt. schools that have become 'tiny' or 'small' - is largely the result of an exodus of students from government schools and migration towards private schools, since there has been no drop in the child population. On the contrary, over the period under consideration, there has been a substantial increase of $4.3 \%$ in the absolute primary-school-age population of $6-10$ year olds in India between 2009 and 2014 (IMRB Surveys 2009, 2014), see Annex Table 1.

Table 1

Percentage of children studying in private unaided schools in India, by age and area, 2014-15

\begin{tabular}{lcccc}
\hline \hline & Age & Rural & Urban & Total \\
$6-10$ & 20.8 & 48.9 & 31.8 \\
$11-14$ & 17.5 & 40.7 & 27.0 \\
$15-18$ & 24.5 & 36.1 & 29.6 \\
\hline \hline Total & 20.8 & 42.1 & 29.6 \\
\hline \hline
\end{tabular}

Source: Author's calculations from the National Sample Survey raw data, $71^{\text {st }}$ Round, 2014-15.

Note: ASER (2014) data show that 30\% of rural 6-14 year olds attended private schools in rural India in 2014 which is higher than the numbers given here, but ASER combines aided and unaided private schools while the above table is for purely private unaided schools. 
Table 2

Percentage of children in private unaided schools, by state, 2014-15

\begin{tabular}{|c|c|c|c|c|c|c|c|c|c|}
\hline & \multicolumn{4}{|c|}{ RURAL } & \multicolumn{4}{|c|}{ URBAN } & \multirow{2}{*}{$\begin{array}{c}\text { TOTAL } \\
\text { State } \\
\text { Total } \\
\end{array}$} \\
\hline & $\begin{array}{l}\text { Age } \\
6-10 \\
\end{array}$ & $\begin{array}{c}\text { Age } \\
11-14 \\
\end{array}$ & $\begin{array}{c}\text { Age } \\
15-18\end{array}$ & $\begin{array}{c}\text { Rural } \\
\text { Total } \\
\end{array}$ & $\begin{array}{l}\text { Age } \\
6-10 \\
\end{array}$ & $\begin{array}{c}\text { Age } \\
11-14 \\
\end{array}$ & $\begin{array}{c}\text { Age } \\
15-18 \\
\end{array}$ & $\begin{array}{c}\text { Urban } \\
\text { Total } \\
\end{array}$ & \\
\hline ANDHRA PRADESH & 28.3 & 17.0 & 52.3 & 31.9 & 69.2 & 55.6 & 67.9 & 64.5 & 47.8 \\
\hline ASSAM & 5.1 & 4.5 & 5.2 & 5.0 & 25.5 & 26.7 & 23.5 & 25.3 & 9.0 \\
\hline BIHAR & 10.6 & 9.2 & 12.3 & 10.6 & 43.8 & 31.3 & 23.0 & 33.2 & 18.2 \\
\hline CHHATTISGARH & 6.8 & 10.0 & 8.8 & 8.4 & 47.5 & 41.9 & 37.5 & 42.7 & 22.4 \\
\hline DELHI & 43.8 & 34.8 & 40.0 & 39.1 & 33.6 & 28.6 & 23.1 & 28.8 & 29.4 \\
\hline GUJARAT & 4.9 & 4.9 & 14.7 & 7.7 & 27.7 & 24.1 & 22.2 & 24.8 & 15.4 \\
\hline HARYANA & 40.1 & 29.6 & 39.4 & 36.7 & 72.7 & 68.9 & 58.0 & 67.2 & 51.2 \\
\hline HIMACHAL PRADESH & 33.3 & 21.1 & 18.7 & 24.3 & 62.3 & 48.1 & 35.3 & 49.4 & 28.7 \\
\hline JAMMU \& KASHMIR & 36.7 & 29.0 & 15.6 & 27.8 & 72.5 & 60.1 & 26.8 & 53.0 & 37.1 \\
\hline JHARKHAND & 8.9 & 9.6 & 16.0 & 10.8 & 45.3 & 47.3 & 41.4 & 44.7 & 23.5 \\
\hline KARNATAKA & 12.8 & 9.7 & 19.2 & 13.8 & 42.1 & 34.9 & 31.6 & 36.5 & 24.6 \\
\hline KERALA & 36.3 & 20.3 & 25.9 & 27.2 & 45.7 & 31.7 & 32.6 & 36.6 & 32.0 \\
\hline MADHYA PRADESH & 17.3 & 15.3 & 18.8 & 17.0 & 53.1 & 48.1 & 48.3 & 50.0 & 31.0 \\
\hline MAHARASHTRA & 7.9 & 3.6 & 8.6 & 6.7 & 26.4 & 19.8 & 15.0 & 20.3 & 13.1 \\
\hline NORTHEAST STATES* & 18.5 & 14.9 & 17.1 & 17.1 & 38.7 & 31.5 & 28.4 & 32.9 & 23.0 \\
\hline ODISHA & 8.4 & 4.5 & 22.1 & 10.4 & 33.9 & 26.2 & 30.8 & 30.3 & 15.8 \\
\hline PUNJAB & 36.7 & 32.5 & 30.8 & 33.5 & 64.5 & 60.5 & 44.4 & 56.2 & 44.4 \\
\hline RAJASTHAN & 36.7 & 35.0 & 44.6 & 38.3 & 77.1 & 74.9 & 58.8 & 70.1 & 50.9 \\
\hline TAMIL NADU & 32.1 & 14.4 & 36.0 & 27.2 & 57.5 & 40.4 & 44.7 & 47.5 & 37.0 \\
\hline TELENGANA & 41.6 & 34.2 & 58.0 & 45.3 & 82.5 & 75.3 & 74.6 & 77.6 & 62.0 \\
\hline UTTAR PRADESH & 38.1 & 41.5 & 42.8 & 40.5 & 69.2 & 61.6 & 47.3 & 60.0 & 47.2 \\
\hline UTTARANCHAL & 14.4 & 12.2 & 14.0 & 13.5 & 67.0 & 64.8 & 42.3 & 57.9 & 30.6 \\
\hline WEST BENGAL & $\underline{6.0}$ & 2.8 & 6.0 & 4.9 & 24.5 & 13.2 & 14.7 & 17.4 & 10.2 \\
\hline India Total & 20.8 & 17.5 & 24.5 & 20.8 & 48.9 & 40.7 & 36.1 & 42.1 & 29.6 \\
\hline
\end{tabular}

Source: Author's calculations from the raw data of the National Sample Survey, $71^{\text {st }}$ Round, 2014-15.

Notes: *The average of the Northeast states; these are Arunachal Pradesh, Manipur, Meghalaya, Mizoram, Nagaland, Sikkim and Tripura. 
Table 3

Percentage of schools of different management-types (from raw DISE data, 2015-16)

\begin{tabular}{|c|c|c|c|c|c|c|}
\hline $\begin{array}{c}\text { School } \\
\text { Management }\end{array}$ & $\begin{array}{l}\text { Government } \\
\text { Schools }\end{array}$ & $\begin{array}{c}\text { Private } \\
\text { Aided } \\
\text { School }\end{array}$ & $\begin{array}{c}\text { Private } \\
\text { Unaided } \\
\text { recognised } \\
\text { School } \\
\end{array}$ & $\begin{array}{l}\text { Private unaided } \\
\text { unrecognised } \\
\text { Schools }\end{array}$ & Madarsas & Total \\
\hline Andhra Pradesh & 73.5 & 3.8 & 21.9 & 0.6 & 0.3 & 100 \\
\hline Assam & 76.1 & 6.0 & 5.9 & 11.6 & 0.4 & 100 \\
\hline Bihar & 89.1 & 0.3 & 4.1 & 5.1 & 1.5 & 100 \\
\hline Chhattisgarh & 87.5 & 0.8 & 11.2 & 0.0 & 0.4 & 100 \\
\hline Gujrat & 76.8 & 1.8 & 21.4 & 0.0 & 0.0 & 100 \\
\hline Haryana & 65.6 & 1.0 & 29.7 & 3.7 & 0.1 & 100 \\
\hline Himachal Pradesh & 85.4 & 0.0 & 14.6 & 0.0 & 0.0 & 100 \\
\hline Jammu \& Kashmir & 81.6 & 0.0 & 18.4 & 0.0 & 0.0 & 100 \\
\hline Jharkhand & 85.2 & 2.4 & 3.1 & 9.0 & 0.3 & 100 \\
\hline Karnataka & 73.8 & 5.1 & 21.1 & 0.0 & 0.0 & 100 \\
\hline Kerala & 27.8 & 41.7 & 20.4 & 10.1 & 0.0 & 100 \\
\hline Madhya Pradesh & 80.3 & 0.7 & 17.9 & 0.0 & 1.2 & 100 \\
\hline Maharashtra & 68.5 & 18.5 & 12.4 & 0.5 & 0.0 & 100 \\
\hline Odisha & 84.8 & 7.0 & 5.3 & 2.8 & 0.0 & 100 \\
\hline Punjab & 71.2 & 1.6 & 23.3 & 3.8 & 0.1 & 100 \\
\hline Rajasthan & 65.5 & 0.0 & 32.3 & 0.0 & 2.2 & 100 \\
\hline Tamil Nadu & 66.4 & 14.6 & 18.7 & 0.3 & 0.0 & 100 \\
\hline Telangana & 70.3 & 1.8 & 26.5 & 0.4 & 1.1 & 100 \\
\hline Uttar Pradesh & 65.6 & 3.3 & 29.4 & 0.0 & 1.7 & 100 \\
\hline Uttaranchal & 74.0 & 2.3 & 22.2 & 0.8 & 0.7 & 100 \\
\hline West Bengal & 86.4 & 0.3 & 9.9 & 1.7 & 1.7 & 100 \\
\hline Major 20 States & 74.5 & 4.4 & 18.5 & 1.7 & 0.9 & 100 \\
\hline
\end{tabular}

Source: www.dise.in/statereportcards/rawdata201415

Note: 'Government schools' includes Dept. of Education schools, Tribal and Social Welfare Dept. schools, Local Body schools and Central govt. schools. 
Table 4

Change in the number of Government and Private schools, by state (2010-11 to 2015-16)

\begin{tabular}{|c|c|c|c|c|c|c|}
\hline \multirow[t]{2}{*}{ State } & \multicolumn{3}{|c|}{ Government schools } & \multicolumn{3}{|c|}{ Private schools } \\
\hline & $2010-11$ & $2015-16$ & Change & $2010-11$ & 2015-16 & Change \\
\hline Andhra Pradesh* & 79314 & 73078 & -6236 & 24823 & 25159 & 336 \\
\hline Assam & 44371 & 50143 & 5772 & 13144 & 11821 & -1323 \\
\hline Bihar & 67930 & 71411 & 3481 & 1423 & 8534 & 7111 \\
\hline Chhattisgarh & 46390 & 44387 & -2003 & 4552 & 5918 & 1366 \\
\hline Gujarat & 33531 & 33843 & 312 & 6405 & 9418 & 3013 \\
\hline Haryana & 14955 & 14598 & -357 & 5549 & 7443 & 1894 \\
\hline Himachal Pradesh & 15126 & 15386 & 260 & 2285 & 2638 & 353 \\
\hline Jammu-Kashmir & 22180 & 23329 & 1149 & 4915 & 5249 & 334 \\
\hline Jharkhand & 40517 & 40437 & -80 & 2949 & 5870 & 2921 \\
\hline Karnataka & 46522 & 45556 & -966 & 10259 & 13063 & 2804 \\
\hline Kerala & 4958 & 4573 & -385 & 906 & 5023 & 4117 \\
\hline Madhya Pradesh & 111943 & 114465 & 2522 & 23710 & 27194 & 3484 \\
\hline Maharashtra & 68691 & 67294 & -1397 & 9775 & 12737 & 2962 \\
\hline Odisha & 57171 & 58476 & 1305 & 4347 & 5642 & 1295 \\
\hline Punjab & 20238 & 20488 & 250 & 10139 & 7820 & -2319 \\
\hline Rajasthan & 77529 & 70664 & -6865 & 26760 & 37267 & 10507 \\
\hline Tamil Nadu & 36120 & 38200 & 2080 & 10622 & 10946 & 324 \\
\hline Uttar Pradesh & 151448 & 161329 & 9881 & 41961 & 76546 & 34585 \\
\hline Uttaranchal & 17345 & 17505 & 160 & 4823 & 5616 & 793 \\
\hline West Bengal & 79323 & 82737 & 3414 & 10227 & 12733 & 2506 \\
\hline India (20 states) & $10,35,602$ & $10,47,899$ & 12,297 & $2,19,574$ & $2,96,637$ & 77,063 \\
\hline
\end{tabular}

Source: DISE raw data, from www.dise.in

Note: *Andhra Pradesh here includes Telengana even in 2015-16, in order to permit comparison with 2010-11. Thus the reduction in the number of govt schools in Andhra Pradesh by 2015-16 here is not due to any removal of Telengana. 
Table 5

Change in student enrolment in Government and Private schools, by state (2010-11 to 2015-16)

\begin{tabular}{|c|c|c|c|c|c|c|c|c|c|c|c|c|}
\hline & \multicolumn{6}{|c|}{ Total student Enrolment } & \multicolumn{6}{|c|}{ Average Enrolment Per School } \\
\hline & \multicolumn{3}{|c|}{ Government schools } & \multicolumn{3}{|c|}{ Private schools } & \multicolumn{3}{|c|}{ Government } & \multicolumn{3}{|c|}{ Private } \\
\hline & 2010-11 & 2015-16 & Change & 2010-11 & 2015-16 & Change & 2010-11 & 2015-16 & Change & 2010-11 & 2015-16 & Change \\
\hline Andhra Pradesh* & 6186492 & 5367402 & -819090 & 4592255 & 49943739 & 351484 & 78 & 73 & -5 & 185 & 196 & 11 \\
\hline Assam & 4082132 & 4140192 & 58060 & 998944 & 1013270 & 14326 & 92 & 83 & -9 & 76 & 86 & 10 \\
\hline Bihar & 19495910 & 21548010 & 2052100 & 404132 & 1812378 & 1408246 & 287 & 302 & 15 & 284 & 212 & -72 \\
\hline Chhattisgarh & 3808619 & 3281257 & -527362 & 755632 & 1113912 & 358280 & 82 & 74 & -8 & 166 & 188 & 22 \\
\hline Gujarat & 5901456 & 5816280 & -85176 & 2017575 & 3031588 & 1014013 & 176 & 172 & -4 & 315 & 322 & 7 \\
\hline Haryana & 2093700 & 1663752 & -429948 & 1304015 & 2006442 & 702427 & 140 & 114 & -26 & 235 & 270 & 35 \\
\hline Himachal Pradesh & 745712 & 580395 & -165317 & 284026 & 370371 & 86345 & 49 & 38 & -11 & 124 & 140 & 16 \\
\hline Jammu-Kashmir & 1213246 & 1024643 & -188603 & 786400 & 832133 & 45733 & 55 & 44 & -11 & 160 & 159 & -1 \\
\hline Jharkhand & 5591346 & 4727894 & -863452 & 928935 & 1508344 & 579409 & 138 & 117 & -21 & 315 & 257 & -58 \\
\hline Karnataka & 4624287 & 4043609 & -580678 & 2328793 & 3007783 & 678990 & 99 & 89 & -10 & 227 & 230 & 3 \\
\hline Kerala & 1075886 & 859682 & -216204 & 375084 & 1471373 & 1096289 & 217 & 188 & -29 & 414 & 293 & -121 \\
\hline Madhya Pradesh & 10634585 & 7979148 & -2655437 & 4623450 & 4720051 & 96601 & 95 & 70 & -25 & 195 & 174 & -21 \\
\hline Maharashtra & 7418628 & 5937688 & -1480940 & 2433975 & 3803480 & 1369505 & 108 & 88 & -20 & 249 & 299 & 50 \\
\hline Odisha & 5659929 & 5053711 & -606218 & 599886 & 992117 & 392231 & 99 & 86 & -13 & 138 & 176 & 38 \\
\hline Punjab & 2165466 & 2072324 & -93142 & 1642518 & 1760579 & 118061 & 107 & 101 & -6 & 162 & 225 & 63 \\
\hline Rajasthan & 7132668 & 6264557 & -868111 & 4736520 & 6073144 & 1336624 & 92 & 89 & -3 & 177 & 163 & -14 \\
\hline Tamil Nadu & 4262160 & 4170562 & -91598 & 3250332 & 3196288 & -54044 & 118 & 109 & -9 & 306 & 292 & -14 \\
\hline Uttar Pradesh & 19688240 & 16602404 & -3085836 & 10280445 & 17622294 & 7341849 & 130 & 103 & -27 & 245 & 230 & -15 \\
\hline Uttaranchal & 936630 & 757137 & -179493 & 617344 & 886874 & 269530 & 54 & 43 & -11 & 128 & 158 & 30 \\
\hline West Bengal & 13484910 & 11193885 & -2291025 & 1349964 & 1662095 & 312131 & 170 & 135 & -35 & 132 & 131 & -1 \\
\hline India (20 states) & $12,62,02,002$ & $11,30,84,532$ & $-1,31,17,470$ & $4,43,10,225$ & $6,18,28,256$ & $1,75,18,031$ & 122 & 108 & -14 & 202 & 208 & 6 \\
\hline
\end{tabular}

Source: DISE raw data, from www.dise.in

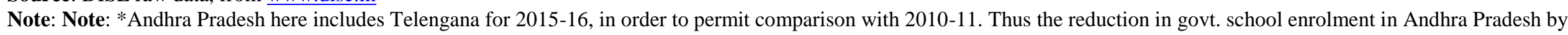

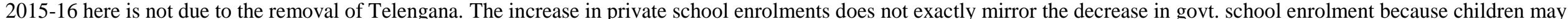

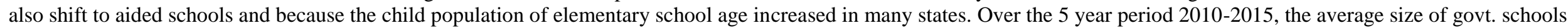
fell by $12 \%$; the average size of private schools rose by $3 \%$, despite the large increase in the number of private schools. 
Table 6

Emptying of government schools over time in India

(The phenomenon of small and tiny government schools, and changes in it, over time)

\begin{tabular}{|c|c|c|c|c|c|c|c|c|}
\hline $\begin{array}{l}\text { Govt. schools } \\
\text { with total pupil } \\
\text { enrolment of: }\end{array}$ & $\begin{array}{c}\text { Number of } \\
\text { Govt. } \\
\text { Schools }\end{array}$ & $\begin{array}{c}\text { Number of } \\
\text { Teachers in } \\
\text { Govt. Schools }\end{array}$ & \begin{tabular}{l}
\multicolumn{1}{c}{ Total } \\
Enrolment in \\
Govt. Schools
\end{tabular} & $\begin{array}{c}\text { Average } \\
\text { pupils per } \\
\text { school } \\
\end{array}$ & $\begin{array}{c}\text { Pupil } \\
\text { teacher } \\
\text { ratio }\end{array}$ & $\begin{array}{c}\text { Teacher } \\
\text { Salary } \\
\text { Expenditure } \\
\text { (Rs. Crores) }\end{array}$ & $\begin{array}{l}\text { Govt. Annual } \\
\text { Per-pupil } \\
\text { Salary Exp. } \\
\text { (Rupees) }\end{array}$ & $\begin{array}{c}\text { Govt. Monthly } \\
\text { Per-pupil } \\
\text { salary Exp. } \\
\text { (Rupees) } \\
\end{array}$ \\
\hline \multicolumn{9}{|l|}{ 2010-11 } \\
\hline Zero & 4,435 & 14,304 & 0 & 0 & 0 & 486 & --- & --- \\
\hline 5 or Less & 8,675 & 21,277 & 15,333 & 1.8 & 0.7 & 724 & $4,71,866$ & 39,322 \\
\hline 10 or Less & 21,008 & 42,843 & $1,18,166$ & 5.6 & 2.8 & 1,457 & $1,23,288$ & 10,274 \\
\hline 20 or Less & 71,189 & $1,38,033$ & $9,20,254$ & 12.9 & 6.7 & 4,694 & 51,005 & 4,250 \\
\hline 50 or Less & $3,13,169$ & $6,33,323$ & $95,10,902$ & 30.4 & 15.0 & 21,536 & 22,643 & 1,887 \\
\hline All govt. sch. & $10,35,602$ & & & & & & & \\
\hline & & & & & & & & \\
\hline \multicolumn{9}{|l|}{ 2015-16 } \\
\hline$\overline{\text { Zero }}$ & 5,044 & 6,961 & 0 & 0 & 0 & 334 & --- & --- \\
\hline 5 or Less & 12,196 & 19,419 & 26,186 & 2.1 & 1.3 & 1,016 & $3,87,992$ & 32,333 \\
\hline 10 or Less & 31,963 & 55,822 & $1,90,340$ & 6.0 & 3.4 & 2,921 & $1,53,441$ & 12,787 \\
\hline 20 or Less & $1,08,183$ & $2,08,534$ & $13,94,126$ & 12.9 & 6.7 & 10,910 & 78,260 & 6,522 \\
\hline 50 or Less & $4,18,825$ & $9,23,929$ & $11,7,43,182$ & 28.0 & 12.7 & 48,340 & 41,164 & 3,430 \\
\hline All govt. sch. & $10,47,895$ & & & & & & & \\
\hline & & & & & & & & \\
\hline \multicolumn{9}{|c|}{ Change between 2010 and 2015} \\
\hline Zero & +609 & $-7,343$ & 0 & +0.0 & +0.0 & -152 & --- & --- \\
\hline 5 or Less & $+3,521$ & $-1,858$ & $+10,853$ & +0.3 & +0.6 & +292 & $-83,874$ & $-6,989$ \\
\hline 10 or Less & $+10,955$ & $+12,979$ & $+72,174$ & +0.4 & +0.6 & $+1,464$ & $+30,153$ & $+2,513$ \\
\hline 20 or Less & $+36,994$ & $+70,501$ & $+4,73,872$ & +0.0 & +0.0 & $+6,216$ & $+27,255$ & $+2,272$ \\
\hline 50 or Less & $+1,05,656$ & $+2,90,606$ & $+22,32,280$ & -2.4 & -2.3 & $+26,804$ & $+18,521$ & $+1,543$ \\
\hline
\end{tabular}

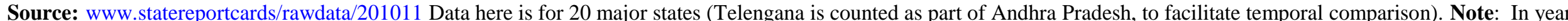

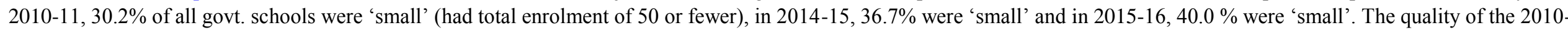

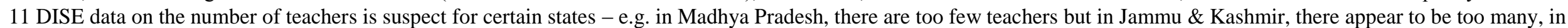

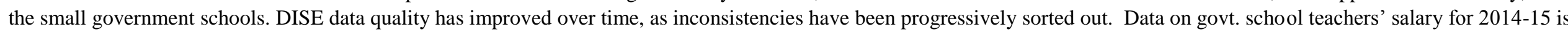

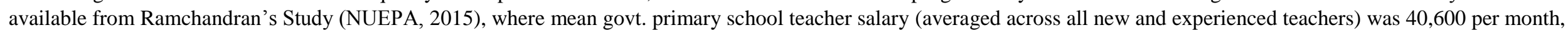

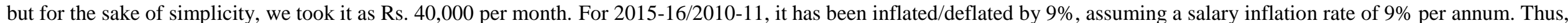

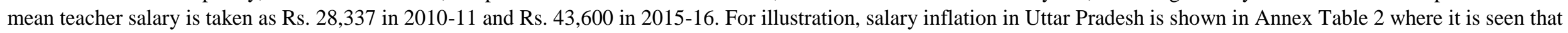
total take-home salary has increased by more than $15 \%$ each year between 2008 and 2017 , or if we take only the $2010-2016$ period, by $8.5 \%$ per annum. 
Table 7

Speed of emptying of government schools, by state

(or the Speed of growth of 'tiny' and 'small' govt. schools, by state)

\begin{tabular}{|c|c|c|c|c|c|c|c|c|}
\hline & \multicolumn{4}{|c|}{ No. of 'tiny' Govt. schools (with 20 or fewer pupils) } & \multicolumn{4}{|c|}{ No. of 'small' Govt. schools (with 50 or fewer pupils) } \\
\hline & \multirow[t]{2}{*}{ 2010-11 } & \multirow[t]{2}{*}{ 2015-16 } & \multicolumn{2}{|c|}{$\begin{array}{l}\text { Increase in number of } \\
\text { 'tiny' govt. schools }\end{array}$} & \multirow[t]{2}{*}{ 2010-11 } & \multirow[t]{2}{*}{ 2015-16 } & \multicolumn{2}{|c|}{$\begin{array}{l}\text { Increase in number of } \\
\text { 'small' govt. schools }\end{array}$} \\
\hline & & & Abs. increase & $\%$ increase & & & Abs. increase & $\%$ increase \\
\hline Andhra Pradesh* & 8,594 & 12,359 & 3765 & 43.8 & 38,397 & 39,615 & 1,218 & 3.2 \\
\hline Assam & 3,938 & 5,847 & 1,909 & 48.5 & 17,034 & 22,107 & 5,073 & 29.8 \\
\hline Bihar & 826 & 12 & -814 & -98.5 & 1,993 & 1,373 & -620 & -31.1 \\
\hline Chhattisgarh & 3,757 & 4,832 & 1,075 & 28.6 & 17,608 & 19,736 & 2,128 & 12.1 \\
\hline Gujarat & 1,018 & 1,471 & 453 & 44.5 & 6,845 & 7,710 & 865 & 12.6 \\
\hline Haryana & 524 & 725 & 201 & 38.4 & 2,699 & 3,775 & 1,076 & 39.9 \\
\hline Himachal Pradesh & 3,320 & 5,541 & 2,221 & 66.9 & 9,912 & 12,000 & 2,088 & 21.1 \\
\hline Jharkhand & 782 & 1,807 & 1,025 & 131.1 & 8,212 & 13,432 & 5,220 & 63.6 \\
\hline Jammu \& Kashmir & 5,776 & 6,815 & 1,039 & 18.0 & 14,373 & 16,344 & 1,971 & 13.7 \\
\hline Karnataka & 8,219 & 10,492 & 2,273 & 27.7 & 21,153 & 22,861 & 1,708 & 8.1 \\
\hline Kerala & 208 & 360 & 152 & 73.1 & 1,011 & 1,396 & 385 & 38.1 \\
\hline Madhya Pradesh & 3,577 & 11,625 & 8,048 & 225.0 & 29,936 & 53,856 & 23,920 & 79.9 \\
\hline Maharashtra & 11,317 & 12,859 & 1,542 & 13.6 & 32,079 & 53,762 & 21,683 & 67.6 \\
\hline Odisha & 2,817 & 5,113 & 2,296 & 81.5 & 19,163 & 25,387 & 6,224 & 32.5 \\
\hline Punjab & 1,077 & 1,392 & 315 & 29.2 & 5,865 & 7,162 & 1,297 & 22.1 \\
\hline Rajasthan & 3,770 & 7,595 & 3,825 & 101.5 & 26,178 & 29,327 & 3,149 & 12.0 \\
\hline Tamil Nadu & 2,058 & 3,098 & 1,040 & 50.5 & 13,614 & 14,769 & 1,155 & 8.5 \\
\hline Uttarakhand & 4,270 & 7,038 & 2,768 & 64.8 & 11,497 & 13,383 & 1,886 & 16.4 \\
\hline Uttar Pradesh & 4,179 & 4,789 & 610 & 14.6 & 22,438 & 33,651 & 11,213 & 50.0 \\
\hline West Bengal & 1,162 & 4,413 & 3,251 & 279.8 & 13,162 & 27,179 & 14,017 & 106.5 \\
\hline India (20 major states) & 71,189 & 108,183 & 36,994 & 52.0 & 313,169 & 418,825 & 105,656 & 33.7 \\
\hline
\end{tabular}

Note : Telengana has been included as part of Andhra Pradesh, for both 2010-11 and 2015-16, in order to aid comparison over time.

Source: DISE raw data from www.dise.in. Analysis has been done for 20 major states of India. 


\section{Fee levels of private schools}

What are the fee levels of private unaided schools, and can we benchmark them as 'high' or 'low'? While there is no official data collected from private schools on fee levels, fortunately

the questionnaire of the $71^{\text {st }}$ Round National Sample Survey (NSS) of 2014-15 included - in its Section 6 - detailed questions on education expenditure on each individual person aged 5-29 years old in the sample households. The variable we take as the measure of school fee is named in the survey as: "Course fee (including tuition fee, examination fee, development fee and other compulsory payments)". The survey also asks separately for expenditure on "books, stationery and uniform", on "transport", and on "private coaching", which we have not taken into account, as we were interested in isolating only the course fee including all compulsory payments that parents pay to the school as fee.

To find out the fee levels of private schools, we took the sub-set of children who report studying in private unaided schools and are aged between 6 and 14 years old, the elementary school age group. These children are of the age to which the Right to Education (RTE) Act 2009 applies, and are meant to be in classes 1 to 8 . The mean and median 'total course fee' in private unaided schools, computed from the NSS data, are presented in Table 8, but before turning to that, it is worth noting how this total course fee is distributed.

Graph 1 shows that total fee is very log-normally distributed, with a pronounced rightward skew, rather than normally distributed with the standard Gaussian bellshape. When a quantity is log-normally distributed, the median is a better measure of central tendency than the mean since it down-weights the undue importance of the few very high values, i.e., it does not permit undue influence of the extremely high fee levels of the few children who study in the very high-fee elite schools. Hence in Table 8, although we present both private unaided schools' mean and median fee levels, it is preferable to focus on the median fee levels.

Table 8 shows that median private unaided school fee level in urban India was Rs. $500 \mathrm{pm}$ and in rural India Rs. $275 \mathrm{pm}$. Taking all India (rural and urban), the median fee was Rs. 417 per month (or Rs. 5000 per annum).

However, there is a great deal of inter-state variation in private school fee levels. For example, from Rs. 117 pm in rural Uttar Pradesh to Rs. 692 pm (six times higher) in rural Punjab; or from Rs. 250 pm in urban UP to Rs. 1800 pm (seven times higher), in urban Delhi.

Graph 2 shows a scatter plot with states' median rural private school fee level on the $x$-axis and on the $y$-axis a measure of the quality of rural govt. schools in the state (measured by the percentage of students of govt. schools with various given literacy and numeracy skills, from ASER data). This plot shows a positive - if somewhat concave - relationship between raw private school fee levels and govt. school quality level, suggesting that the better functioning are the government schools in a state, the less the need felt by poor parents for private education, and thus the more elite (the more high fee charging) the private schools in that state. Similarly, the worse the government school quality in a state, the greater the perceived need by even the 
poorer families to demand private schooling of any description, leading to the higher supply of a lot of even 'low-fee' budget private schools.

\section{Graph 1}

Distribution of private unaided schools' fee levels, Age 6-14, India, 2014-15

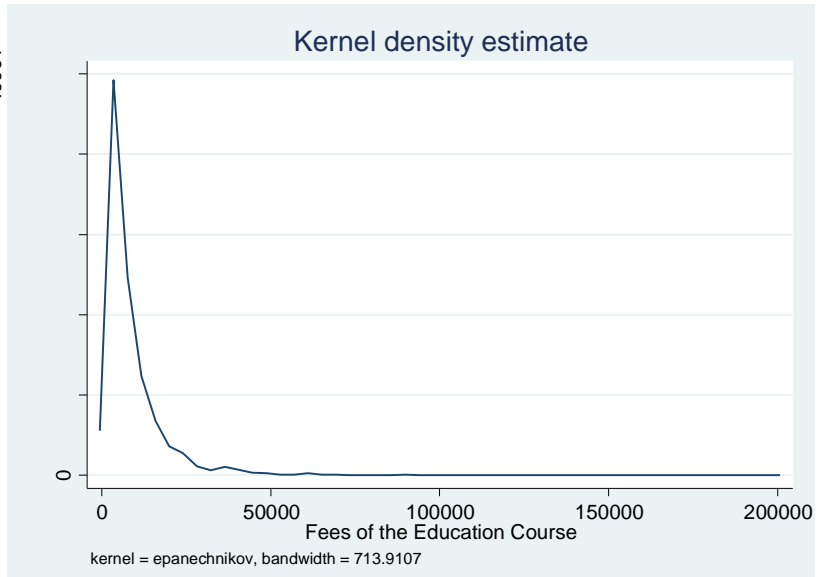

\section{Graph 1a}

Distribution of (annual) fee level without constraining the fee values. Notice that a very tiny number of students report paying fee from Rupees 50,000 to Rupees 2 lakh per annum (above about Rs. 4000 pm).

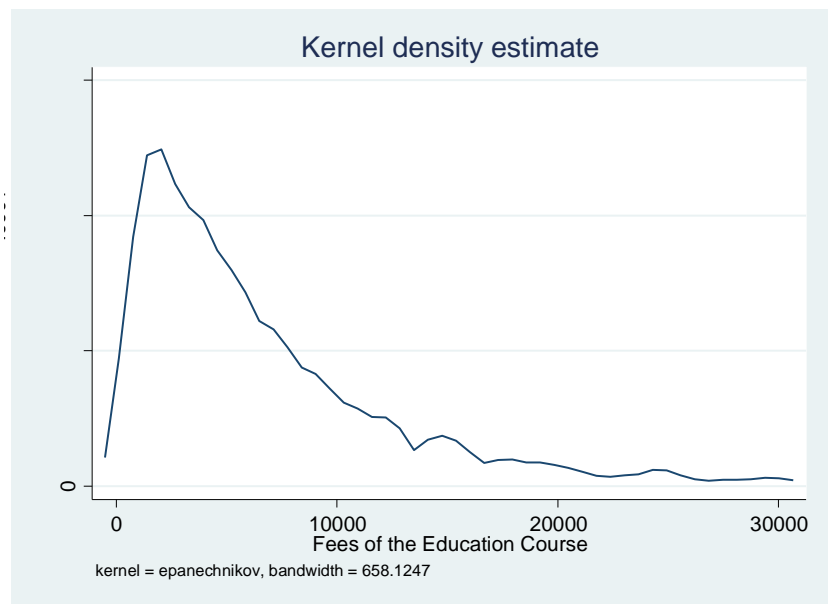

\section{Graph 1b}

Distribution of (annual) fee level after constraining the fee values to be below Rs. 30,000 pa (Rs. 2500 pm). Even here, it is visible that only a very small number of students pay fees above around Rs. 12,000 pa or Rs. 1000 pm.

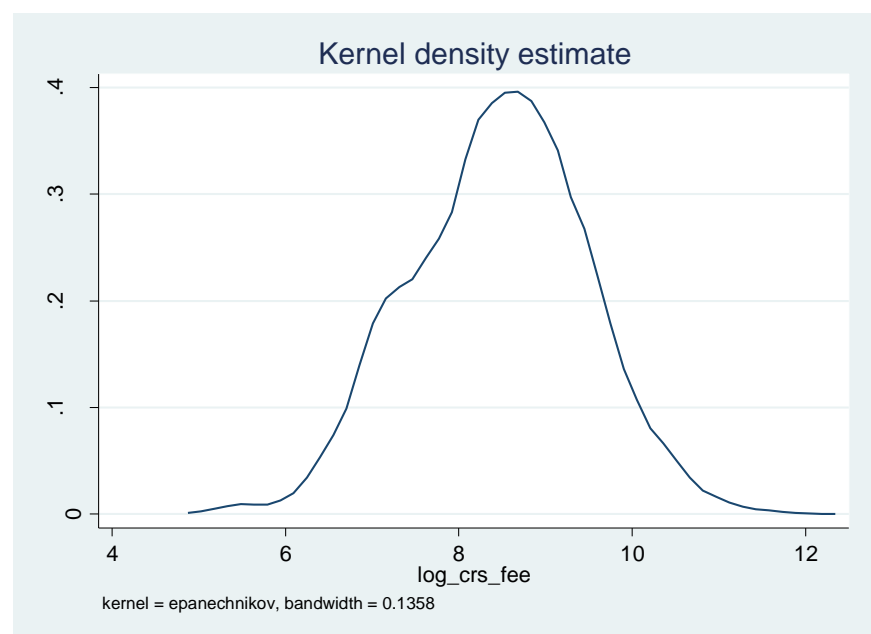

\section{Graph 1c}

This shows the distribution of $\log$ of course fee, rather than of the course fee. It is apparent that this is much more normally distributed (much closer to the bell-shaped 'Gaussian' distribution) than graphs $1 \mathrm{a}$ and $1 \mathrm{~b}$.

Source: Kernel density distribution produced in STATA, using NSS data 2014-15. 
Graph 2

Descriptive relationship between govt. school quality and private school fee levels, by state

(Govt. school quality is measured by the \% of children in rural govt. schools - in given grades - who can do simple literacy and numeracy tasks, and this is shown on the $\mathrm{y}$-axis; the $\mathrm{x}$-axis shows the median fee level in rural private schools. Each point represents a major state of India)

\section{\% Children in Std II} who can recognize...

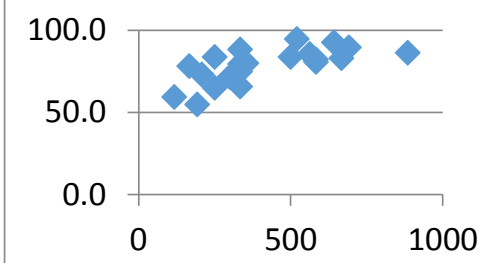

$\diamond \%$ Children in Std II who can recognize numbers 1-9 and more
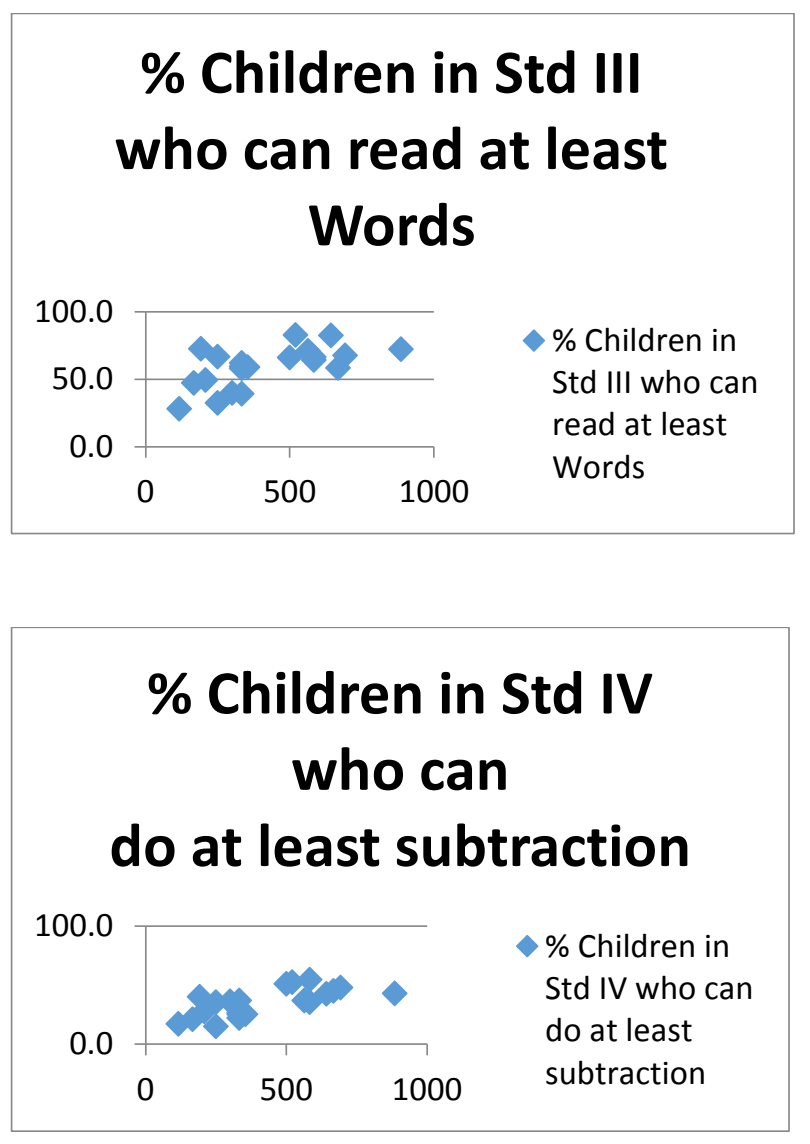
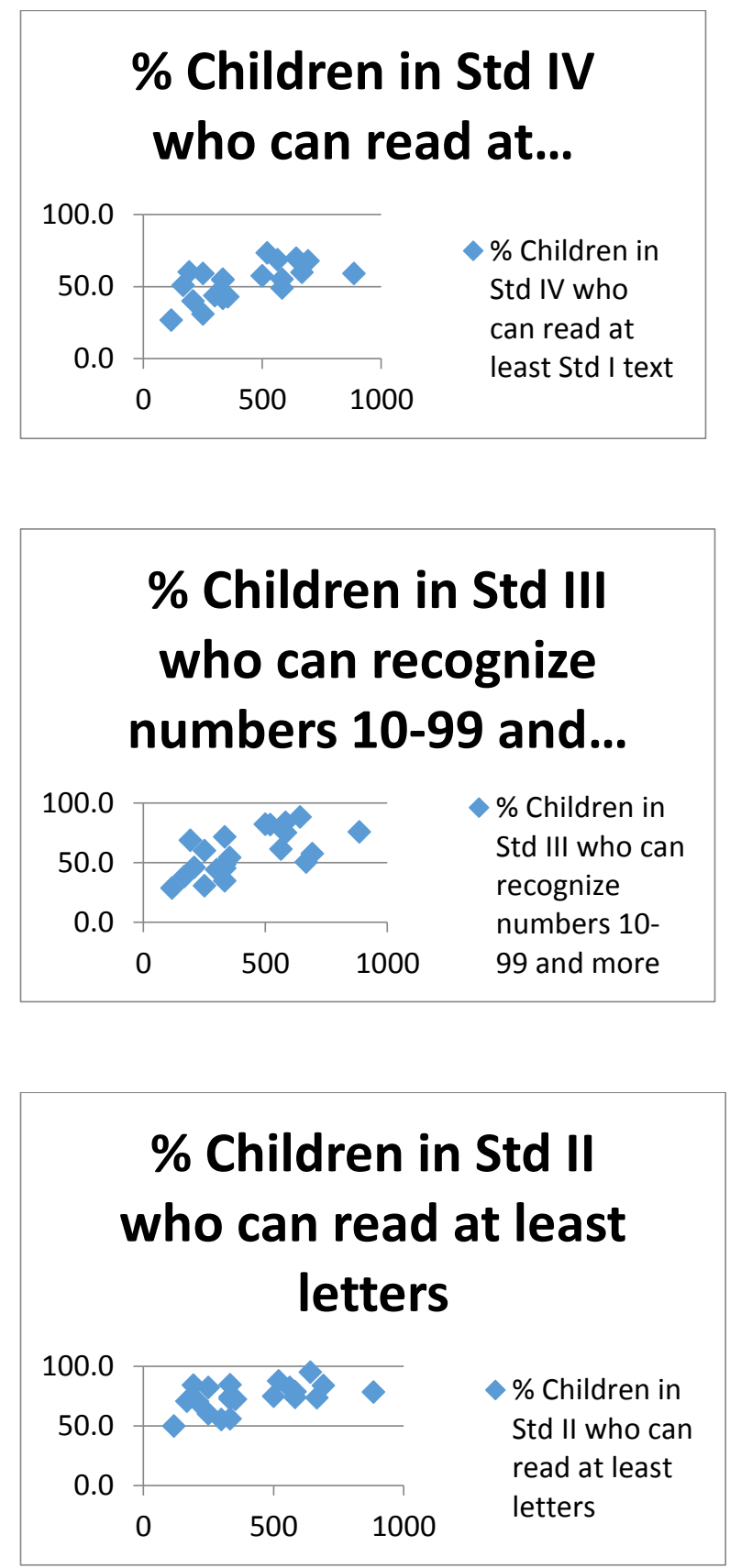
Table 8

Mean and Median Fee Levels in Private Unaided Schools for Children Aged 6-14, by state, 2014-15

\begin{tabular}{|c|c|c|c|c|c|c|c|c|c|c|c|c|}
\hline \multirow[b]{3}{*}{ State } & \multicolumn{6}{|c|}{ Annual Fee } & \multicolumn{6}{|c|}{ Monthly Fee } \\
\hline & \multicolumn{3}{|c|}{ Mean } & \multicolumn{3}{|c|}{ Median } & \multicolumn{3}{|c|}{ Mean } & \multicolumn{3}{|c|}{ Median } \\
\hline & Rural & Urban & Total & Rural & Urban & total & Rural & Urban & Total & Rural & Urban & Total \\
\hline Andhra Pradesh & 7141 & 10300 & 9398 & 6000 & 8500 & 8000 & 595 & 858 & 783 & 500 & 708 & 667 \\
\hline Assam & 5513 & 9049 & 7470 & 4250 & 5700 & 5000 & 459 & 754 & 622 & 354 & 475 & 417 \\
\hline Bihar & 6464 & 6722 & 6633 & 3600 & 4700 & 4200 & 539 & 560 & 553 & 300 & 392 & 350 \\
\hline Chhattisgarh & 2171 & 8851 & 7667 & 2000 & 5000 & 4300 & 181 & 738 & 639 & 167 & 417 & 358 \\
\hline Delhi & 9595 & 25180 & 24198 & 8000 & 21600 & 18750 & 800 & 2098 & 2017 & 667 & 1800 & 1563 \\
\hline Gujarat & 7230 & 8512 & 8260 & 4000 & 5700 & 5400 & 602 & 709 & 688 & 333 & 475 & 450 \\
\hline Haryana & 9431 & 13413 & 12119 & 8000 & 8500 & 8400 & 786 & 1118 & 1010 & 667 & 708 & 700 \\
\hline Himachal Pradesh & 8512 & 9598 & 8859 & 6245 & 8400 & 6700 & 709 & 800 & 738 & 520 & 700 & 558 \\
\hline Jammu \& Kashmir & 4901 & 7483 & 6269 & 4000 & 5600 & 5000 & 408 & 624 & 522 & 333 & 467 & 417 \\
\hline Jharkhand & 5681 & 8054 & 7406 & 2500 & 6800 & 5350 & 473 & 671 & 617 & 208 & 567 & 446 \\
\hline Karnataka & 7940 & 12130 & 11112 & 7000 & 9000 & 8200 & 662 & 1011 & 926 & 583 & 750 & 683 \\
\hline Kerala & 8829 & 10759 & 9990 & 7700 & 8938 & 8400 & 736 & 897 & 833 & 642 & 745 & 700 \\
\hline Madhya Pradesh & 4259 & 6574 & 5823 & 3000 & 4500 & 3700 & 355 & 548 & 485 & 250 & 375 & 308 \\
\hline Maharashtra & 9300 & 13594 & 12630 & 6750 & 9000 & 8000 & 775 & 1133 & 1053 & 563 & 750 & 667 \\
\hline Northeast States* & 6157 & 8574 & 7395 & 4326 & 7190 & 6079 & 513 & 714 & 616 & 361 & 599 & 507 \\
\hline Orissa & 3592 & 7585 & 6032 & 3000 & 5000 & 4000 & 299 & 632 & 503 & 250 & 417 & 333 \\
\hline Punjab & 9893 & 11030 & 10589 & 8300 & 7200 & 7900 & 824 & 919 & 882 & 692 & 600 & 658 \\
\hline Rajasthan & 4961 & 7583 & 6416 & 4000 & 5000 & 4500 & 413 & 632 & 535 & 333 & 417 & 375 \\
\hline Tamil Nadu & 12072 & 12261 & 12197 & 10625 & 10800 & 10800 & 1006 & 1022 & 1016 & 885 & 900 & 900 \\
\hline Telengana & 8176 & 10827 & 10054 & 7000 & 8500 & 8000 & 681 & 902 & 838 & 583 & 708 & 667 \\
\hline Uttar Pradesh & 2264 & 6303 & 4104 & 1400 & 3000 & 1800 & 189 & 525 & 342 & 117 & 250 & 150 \\
\hline Uttarakhand & 8446 & 9501 & 9219 & 4000 & 7800 & 7200 & 704 & 792 & 768 & 333 & 650 & 600 \\
\hline West Bengal & 4571 & 16613 & 13482 & 2300 & 12000 & 7150 & 381 & 1384 & 1124 & 192 & 1000 & 596 \\
\hline Total (weighted mean) & 5396 & 9611 & 7959 & 3500 & 6500 & 5000 & 450 & 801 & 663 & 292 & 542 & 417 \\
\hline
\end{tabular}

Notes: *The average of the Northeast states; these are Arunachal Pradesh, Manipur, Meghalaya, Mizoram, Nagaland, Sikkim and Tripura.

Source: The author's own calculations on raw data from the National Sample Survey $\left(71^{\text {st }}\right.$ Round). 
Table 9

\% of 6-14 year old Private Unaided School attendees who pay fee below given thresholds, by state, 2014-15

\begin{tabular}{|c|c|c|c|c|c|c|c|c|c|c|}
\hline State & $\begin{array}{c}<=100 \text { per } \\
\text { month }\end{array}$ & $\begin{array}{c}<=200 \text { per } \\
\text { month }\end{array}$ & $\begin{array}{c}<=500 \text { per } \\
\text { month }\end{array}$ & $\begin{array}{c}<=750 \text { per } \\
\text { month }\end{array}$ & $\begin{array}{c}<=1000 \text { per } \\
\text { month }\end{array}$ & $\begin{array}{c}<=1500 \text { per } \\
\text { month }\end{array}$ & $\begin{array}{c}<=2000 \text { per } \\
\text { month }\end{array}$ & $\begin{array}{c}<=2500 \text { per } \\
\text { month }\end{array}$ & $\begin{array}{c}\text { Govt. RTE } \\
\text { reimburse- } \\
\text { ment } \\
\text { amount } \\
\text { (per month) } \\
\end{array}$ & \begin{tabular}{|c|}
$\%$ pupils \\
whose fee level \\
is $<$ RTE \\
reimbursement \\
amount \\
\end{tabular} \\
\hline Andhra Pradesh & 2.2 & 5.6 & 38.9 & 61.1 & 73.5 & 91.7 & 96.6 & 98.2 & & \\
\hline Assam & 5.7 & 15.7 & 58.5 & 74.8 & 87.4 & 93.7 & 95.6 & 98.1 & & \\
\hline Bihar & 7.4 & 21.8 & 68.4 & 76.4 & 85.9 & 93.1 & 95.6 & 96.4 & & \\
\hline Chhattisgarh & 9.1 & 30.0 & 60.5 & 69.5 & 75.5 & 81.4 & 84.1 & 90.0 & & \\
\hline Delhi & 3.4 & 5.5 & 14.3 & 26.5 & 34.9 & 49.2 & 59.7 & 69.3 & 1190.0 & 35.2 \\
\hline Gujarat & 4.9 & 21.8 & 61.2 & 74.2 & 85.8 & 90.5 & 93.2 & 96.3 & & \\
\hline Haryana & 1.6 & 5.1 & 36.6 & 56.4 & 68.6 & 85.9 & 92.2 & 95.1 & & \\
\hline Himachal Pradesh & 2.0 & 6.1 & 46.7 & 66.5 & 78.2 & 90.4 & 97.5 & 99.0 & 1593.0 & 91.9 \\
\hline Jammu \& Kashmir & 3.1 & 12.1 & 71.1 & 85.9 & 92.5 & 96.9 & 98.5 & 99.3 & & \\
\hline Jharkhand & 9.2 & 24.5 & 55.0 & 70.9 & 82.3 & 95.0 & 98.9 & 99.3 & & \\
\hline Karnataka & 3.4 & 9.9 & 38.5 & 53.7 & 70.7 & 81.8 & 89.7 & 94.7 & 987.0 & 66.0 \\
\hline Kerala & 1.7 & 4.6 & 31.7 & 54.6 & 73.5 & 90.6 & 96.3 & 97.5 & & \\
\hline Madhya Pradesh & 9.9 & 27.7 & 70.7 & 81.4 & 90.1 & 95.7 & 97.3 & 98.7 & & \\
\hline Maharashtra & 7.6 & 13.7 & 42.4 & 54.0 & 66.9 & 79.9 & 85.5 & 90.2 & & \\
\hline Northeast States* & 4.1 & 10.5 & 51.1 & 79.8 & 92.5 & 96.9 & 97.7 & 98.0 & & \\
\hline Orissa & 12.2 & 30.4 & 69.2 & 85.7 & 90.3 & 94.9 & 96.6 & 97.0 & & \\
\hline Punjab & 2.7 & 7.9 & 40.8 & 57.6 & 71.4 & 84.9 & 90.3 & 95.2 & & \\
\hline Rajasthan & 3.9 & 18.0 & 68.5 & 80.6 & 88.6 & 93.8 & 96.1 & 97.9 & 1383.0 & 92.8 \\
\hline Tamil Nadu & 0.7 & 2.4 & 20.8 & 40.5 & 59.8 & 83.4 & 92.7 & 96.7 & & \\
\hline Telengana & 1.0 & 3.6 & 30.5 & 58.5 & 78.0 & 92.3 & 95.2 & 97.6 & & \\
\hline Uttar Pradesh & 32.7 & 61.2 & 83.2 & 88.2 & 91.5 & 95.2 & 96.5 & 97.4 & 450.0 & 80.6 \\
\hline Uttarakhand & 2.4 & 14.2 & 43.8 & 62.7 & 81.7 & 87.0 & 92.3 & 98.2 & 860.0 & 71.0 \\
\hline West Bengal & 11.7 & 27.4 & 46.3 & 54.9 & 62.0 & 75.1 & 83.7 & 88.6 & & \\
\hline India Total & 11.4 & 25.1 & 57.3 & 71.4 & 81.5 & 90.7 & 94.2 & 96.4 & & \\
\hline
\end{tabular}

Source: for Fee information, National Sample Survey data. Note: See Table 8 for the definition of Northeast States. 
Table 10

Benchmarking private schools' fee levels against (1) state per capita income, (2) Govt. funded schools' PPE, and (3) Minimum wages

\begin{tabular}{|c|c|c|c|c|c|c|c|c|c|}
\hline & \multicolumn{2}{|c|}{$\begin{array}{c}\text { Private school fee, } \\
\text { annual } \\
(2014-15)\end{array}$} & \multirow{2}{*}{$\begin{array}{l}\text { State per capita } \\
\text { GDP } \\
(2014-15) \\
\text { (c) }\end{array}$} & \multirow{2}{*}{$\begin{array}{c}\text { Ratio of } \\
\text { private school } \\
\text { fee to State } \\
\text { per capita GDP } \\
(\mathrm{d})=(\mathrm{a} / \mathrm{c}) * 100 \\
\end{array}$} & \multirow{2}{*}{$\begin{array}{l}\text { Per pupil expense } \\
\text { (PPE) in Govt. } \\
\text { funded schools } \\
(2014-15) \\
(\mathrm{e})\end{array}$} & \multirow{2}{*}{$\begin{array}{c}\text { PPE in govt. } \\
\text { schools as a \% of } \\
\text { state per capita } \\
\text { income } \\
(f)=(\mathrm{e} / \mathrm{c}) * 100\end{array}$} & \multirow{2}{*}{$\begin{array}{l}\text { Minimum Daily } \\
\text { wage } 2014 \\
\text { (for MNREGA } \\
\text { rural workers) } \\
\quad(\mathrm{g})\end{array}$} & \multirow{2}{*}{$\begin{array}{l}\text { Annual Private } \\
\text { sch median fee as } \\
\text { a \% of the annual } \\
\text { minimum wage* } \\
\text { (h) }\end{array}$} & \multirow{2}{*}{$\begin{array}{l}\text { \% rural private school } \\
\text { pupils whose monthly } \\
\text { fee is below the } \\
\text { Minimum Daily wage } \\
\text { (i) }\end{array}$} \\
\hline & Mean (a) & Median (b) & & & & & & & \\
\hline ANDHRA PRADESH & 9398 & 8000 & 90517 & 10.4 & 14087 & 15.6 & 169 & 15.8 & 7.3 \\
\hline ASSAM & 7470 & 5000 & 49480 & 15.1 & --- & --- & 167 & 10.0 & 15.5 \\
\hline BIHAR & 6633 & 4200 & 36143 & 18.4 & 5298 & 14.7 & 158 & 8.9 & 12.8 \\
\hline CHHATTISGARH & 7667 & 4300 & 64442 & 11.9 & 16151 & 25.1 & 157 & 9.1 & 36.2 \\
\hline DELHI & 24198 & 18750 & 251267 & 9.6 & --- & --- & --- & --- & --- \\
\hline GUJARAT & 8260 & 5400 & 122658 & 6.7 & 17106 & 13.9 & 167 & 10.8 & 14.1 \\
\hline HARYANA & 12119 & 8400 & 148563 & 8.2 & 27163 & 18.3 & 236 & 11.9 & 4.3 \\
\hline HIMACHAL PRADESH & 8859 & 6700 & 101542 & 8.7 & 39343 & 38.7 & --- & --- & --- \\
\hline JHARKHAND & 7406 & 5350 & 52589 & 14.1 & 8020 & 15.3 & 158 & 11.3 & 33.8 \\
\hline KARNATAKA & 11112 & 8200 & 93703 & 11.9 & 16914 & 18.1 & 191 & 14.3 & 20.2 \\
\hline KERALA & 9990 & 8400 & 117713 & 8.5 & 19419 & 16.5 & 212 & 13.2 & 5.3 \\
\hline MADHYA PRADESH & 5823 & 3700 & 59770 & 9.7 & 11927 & 20.0 & 157 & 7.9 & 21.6 \\
\hline MAHARASHTRA & 12630 & 8000 & 125833 & 10.0 & 14712 & 11.7 & 168 & 15.9 & 15.8 \\
\hline ODISHA & 6032 & 4000 & 59229 & 10.2 & 9367 & 15.8 & 164 & 8.1 & 34.0 \\
\hline PUNJAB & 10589 & 7900 & 101529 & 10.4 & 9142 & 9.0 & 200 & 13.2 & 5.3 \\
\hline RAJASTHAN & 6416 & 4500 & 71537 & 9.0 & 19391 & 27.1 & 163 & 9.2 & 11.4 \\
\hline TAMIL NADU & 12197 & 10800 & 128366 & 9.5 & 14229 & 11.1 & 167 & 21.6 & 1.6 \\
\hline UTTAR PRADESH & 4104 & 1800 & 40373 & 10.2 & 13102 & 32.5 & 156 & 3.8 & 66.8 \\
\hline UTTARANCHAL & 9219 & 7200 & 115632 & 8.0 & 26236 & 22.7 & 156 & 15.4 & 8.9 \\
\hline WEST BENGAL & 13482 & 7150 & 78903 & 17.1 & 7001 & 8.9 & 169 & 14.1 & 42.9 \\
\hline India (Weighted Mean) & 7671 & 5000 & 83,285 & 9.2 & 11523 & 19.4 & 172.2 & 10.2 & 26.5 \\
\hline
\end{tabular}

Source: For columns (a) and (b), National Sample Survey or NSS data; for column (c) state per capita income (PCI), see http://pib.nic.in/newsite/PrintRelease.aspx?relid=123563.

For a few states, the 2014-15 state PCI was not available so it has been extrapolated from the previous two years' trend growth rate. For Column (e), Dongre and Kapur (2016) who report estimated per pupil expenditure (PPE) in Govt. and Aided schools, based on state budget documents and DISE data, but their PPE figures are serious underestimates (see Annex 1). For column (g), Ministry of Rural Development eands.dacnet.nic.in/Graphs.xlsx (accessed 1.11.2016). *We assume 300 days of work a year. 
Table 11

Private schools' fee compared with Govt. funded schools' per pupil expenditure (PPE) - 2014-15

\begin{tabular}{|c|c|c|c|c|}
\hline & $\begin{array}{l}\text { Median private } \\
\text { school fee } \\
\text { (Rs. per month) }\end{array}$ & $\begin{array}{c}\text { Govt. funded } \\
\text { schools' PPE } \\
\text { (Rs. per month) }\end{array}$ & $\begin{array}{c}\text { Private schools' } \\
\text { fee as a \% of } \\
\text { Govt-funded } \\
\text { schools' PPE }\end{array}$ & $\begin{array}{c}\text { \% private schools } \\
\text { whose fee is lower } \\
\text { than Govt funded } \\
\text { schools' PPE }\end{array}$ \\
\hline & (a) & (b) & $(\mathrm{c})=(\mathrm{a} / \mathrm{b}) * 100$ & (d) \\
\hline Andhra Pradesh & 667 & 1174 & 56.8 & 81.1 \\
\hline Bihar & 350 & 442 & 79.2 & 62.6 \\
\hline Chhattisgarh & 358 & 1346 & 26.6 & 85.7 \\
\hline Gujarat & 450 & 1426 & 31.6 & 89.8 \\
\hline Haryana & 700 & 2264 & 30.9 & 94.2 \\
\hline Himachal Pradesh & 558 & 3279 & 17.0 & 99.5 \\
\hline Jharkhand & 446 & 668 & 66.8 & 65.2 \\
\hline Karnataka & 683 & 1410 & 48.4 & 81.1 \\
\hline Kerala & 700 & 1618 & 43.3 & 91.5 \\
\hline Madhya Pradesh & 308 & 994 & 31.0 & 86.8 \\
\hline Maharashtra & 667 & 1226 & 54.4 & 71.1 \\
\hline Orissa & 333 & 781 & 42.6 & 86.7 \\
\hline Punjab & 658 & 762 & 86.4 & 58.8 \\
\hline Rajasthan & 375 & 1616 & 23.2 & 95.2 \\
\hline Tamil Nadu & 900 & 1186 & 75.9 & 70.0 \\
\hline Uttar Pradesh & 150 & 1092 & 13.7 & 92.9 \\
\hline Uttarakhand & 600 & 2186 & 27.4 & 95.3 \\
\hline West Bengal & 596 & 583 & 102.2 & 48.3 \\
\hline $\begin{array}{l}\text { India (major states) } \\
\text { Weighted means }\end{array}$ & 417 & 1091 & 47.4 & 79.4 \\
\hline
\end{tabular}

Source: NSS (2014-15) data, for column (a) and Dongre \& Kapur (2016) for column (b). Dongre \& Kapur do not report govt. PPE for Delhi, Assam and Jammu \& Kashmir. Columns (c) and (d) are calculated by the author. There is reason to believe Dongre \& Kapur's PPE figures are seriously under-estimated, see Annex 1.

\section{Benchmarking private school fee levels}

Is the private unaided schools' fee observed in Table 8 low or high? Before turning to that, we examine what percentage of private-school students pay fee below given absolute threshold levels. This is presented in Table 9. It shows that in states such as Bihar, Madhya Pradesh, Rajasthan, Uttar Pradesh and Orissa, about 70 to 85 per cent of children studying in private unaided schools are paying fee of less than Rs. 500 per month (Rs 6000 per annum). Only a minority $(15 \%-30 \%)$ of private school attendees pay fees above Rs. 500 pm.

\section{Benchmarking with respect to state per capita income}

One way of benchmarking the size of the private school fee is to see its ratio with respect to the state per capita income. Here, since government reports mean (rather than median) per capita income, we use the mean private school fee level rather 
than the median. Table 10 shows that nationally, private schools' mean fee is around $9.2 \%$ of the state per capita income.

Benchmarking with respect to the minimum wage of daily wage labourers

A second way of benchmarking private school fee is to see to what extent the poorest paid workers can afford private school fee. The last three columns of Table 10 attempt to do that. Srivastava (2013) suggests that a useful way of defining 'low fee' schools is schools where the monthly fee is equal to one day's wage of the daily wage labourers, one of the lowest paid worker groups, who get the minimum daily wage as announced annually by the Ministry of Rural Development. Column (g) of Table 10 shows the officially mandated minimum daily wage of April 2014 for each state. We take it that daily wagers work 300 days a year and thus predict the annual wage for daily-wagers. Expressing the median annual private school fee as a percentage of this annual minimum wage in column (h) shows that, on average, private schools' median annual fee is around $10.2 \%$ of the annual minimum wage of daily wagers. Uttar Pradesh is an outlier, in that private school annual fee is only $3.8 \%$ of the annual earning of daily-wagers in the state, suggesting that even very poor people can access private schooling in Uttar Pradesh, and this is consistent with the high utilisation of private schooling in UP. Another variant for benchmarking private schools' fee is to ask: for what percentage of rural private school pupils is their actual monthly fee below the daily minimum wage of their state. Column (i) shows that, on average, $26 \%$ of rural private school pupils' monthly fee is below their state's daily minimum wage. While UP is again an outlier (with $67 \%$ rural private school pupils' monthly fee being below the minimum daily wage of UP in 2014), in states such as West Bengal, Orissa, Jharkhand and Chattisgarh, the proportion is higher than one-third; it suggests that one third or more of the private schools in these states are 'low fee' schools by this definition, i.e. that educate the poorest children.

Benchmarking with respect to the per pupil expenditure in govt. schools

A third way of benchmarking whether private school fee level in a state is 'high' or 'low', is to compare it with the state's per pupil expenditure (PPE) in the government school system. Table 11 shows the private unaided schools' median fee levels and also the per-pupil expenditure (PPE) in the govt. funded school system, statewise and for India as a whole 9 . It shows that in India as a whole, just under 80 per cent of the private-school-going children study in those private schools where the fee is below the government schools' per pupil expenditure. In a large number of states, more than $90 \%$ of private school students paid fees lower than the estimated PPE in the govt. funded schools. The last column in Table 11 shows that - averaging across the states - private school fee is only $47 \%$ of the PPE in govt-funded schools estimated by Dongre and Kapur (2016), and that is when their calculation of govt. PPE is a serious under-estimate of the true PPE in the govt. school system (for reasons set out in Annex 1). The level of private school fee also has implications for the reimbursement from government to private schools for educating poor and

\footnotetext{
${ }^{9}$ The weighted average across the states for which the PPE data is available. Since government provides free books and uniform to all children attending government schools, the estimate of govt. PPE on education includes govt. expenditure on books and uniforms, but our private school's per pupil expenditure (proxied by the school's fee) does not include expenditure on books and uniforms, which undermines the ability to compare private and public schools' unit costs of education. However, as shown in Annex 1, the PPE estimates for public schools presented here are likely to be serious under-estimates of the true PPE of public schools.
} 
disadvantaged children under the Right to Education Act 2009. Annex 2 spells out the implications.

\section{Policy implications of this benchmarking exercise}

In summary, the above evidence on private unaided schools' fee levels is surprising, and is at odds with popular perceptions, as it shows that a good proportion of private schooling caters to the really poor. The evidence suggests that most private schools in India can be considered "low fee" in the precise sense that their fee is below the government's per pupil expenditure in its own schools. This evidence discredits the oft-repeated belief that much of private schooling in India is elite and exclusive. This realisation is significant because perceptions about the nature of private schools have important implications for the making of policy towards private schools. To take one example, the realisation that in the majority of private schools, fee levels are far lower than government schools' per pupil expenditure draws the education policy maker's attention to the fact that when a high proportion of the well-funded government schools themselves cannot comply with the infrastructure norms of the Right to Education (RTE) Act $2009^{10}$, how can private schools do so (without public subsidy), since the majority of them run on a small fraction of the unit cost of government schools. The kind of data presented here to benchmark private school fee levels can help decision-takers to make more evidence-informed education policy that is more realistic and less wishful, and to avoid counter-productive effects such as the closure of the low-fee private schools which may be successfully imparting learning but which lack the resources to fulfil the demanding infrastructure norms ${ }^{11}$.

\section{Teacher salaries in private schools}

The major factor behind the lower unit-cost of producing education in private than public schools is the much lower teacher salaries of private schools compared with government and aided schools. Unfortunately, there is no systematic documentation or evidence collected by any agency nationally on individual teacher salaries, either for government or private schools. One has to rely on the few sporadic small-scale surveys and studies from individual states. However, fortunately, the National University of Educational Planning and Administration (NUEPA) carried out a two year study of government school teachers across nine Indian states in 2014-15, in collaboration with the State Councils of Educational Research and Training (SCERTs) of these nine states, in which they also collected information on teacher salaries in government schools (Ramachandran, 2015). We use this study for evidence on government school teachers' salaries. For evidence on private school teachers' salaries, we turn to individual small-scale studies from two districts of

\footnotetext{
${ }^{10}$ Section 18 of the RTE Act 2009 stipulates that no private unaided school can be established or continue to function without obtaining a certificate of 'recognition' from the government, and section 19 lays down the various penalties (including closure) for non-compliance with the given norms and conditions. While section $8(\mathrm{~g})$ of the Act specifies as the state's duty to ensure that govt. schools also conform to the norms of the Act, there are no penalties if they do not and thus, de facto, there is no momentum for govt. funded schools to comply.

${ }^{11}$ NISA (2014) calculated that by March 2014, just under 4500 private unaided schools had closed down and just over 15,000 had received closure notices, due to not fulfilling infrastructure norms.
} 
Punjab (CCS, 2014) and extrapolate to 2014 from a 2008 survey of five districts each of Uttar Pradesh and Bihar (SchoolTELLS, 2009).

Firstly, we show in Table 12 evidence on teacher salaries in govt. schools across 6 Indian states reported in Ramachandran (2015). She reports the take-home salary levels of three types of teachers in govt. schools: newly appointed teachers, teachers with 15 years' work experience and teachers with 25 years' experience, each at the primary level and at the secondary level. For simplification, we take the salary of a teacher with 15 years' experience as representing the average salary of teachers in govt. schools. The teachers of junior/upper-primary - classes 6,7 and 8 - are paid salaries equal to secondary school teachers in India, thus the salary shown for secondary teachers are also the salary-levels of the upper-primary teachers. Taking the simple average of salaries across the states, the last row of Table 12 shows that in the school year 2014-15, mean of govt. primary teachers' salary was Rs. 40,623 per month, and the mean of upper-primary teachers' salary was Rs. 51,595 pm, but these do not reflect the other pecuniary benefits that teachers in govt.-funded schools (i.e. govt. and aided schools) enjoy, such as pension and gratuity at the time of retirement.

We present two ways of benchmarking whether this govt. school salary level is high or low: one is to compare govt. teacher salaries with teacher salaries in the private school sector and the other is to compare govt. salaries with the 'state per capita income' $(\mathrm{PCl})$ of the respective states, and then see whether that ratio (of mean teacher salary to $\mathrm{PCI}$ ) is higher than in other countries with which India compares itself.

\section{Benchmarking salary against state per capita income}

Table 13 shows that govt. primary school teacher salary is, on average, about 7 times (and govt. upper-primary teacher salary is about 9 times) the per capita income of the respective states. To simplify, one could say that in India govt. elementary school teachers' salary is - on average - around 8 times the country's per capita income. Table 14 (reproduced from Dreze and Sen, 2013) confirms that this ratio of 8 is very much higher than in China, Pakistan, Indonesia, Bangladesh etc. where the ratio is typically between 1 and 2 . In other words, when seen in relation to the various countries' respective per capita incomes, govt. school teachers in India are 4 to 8 times higher paid than teachers in the other shown countries, a striking finding!

\section{Benchmarking salary against private school teachers' salary}

Table 15 presents the meagre evidence on private school teachers' salaries available from various parts of India in different years. In Kansal's study of Delhi schools in the late 1980s, the average salary of private school teachers was $47 \%$ of the average salary of govt. school teachers, i.e. just under half. In the early 1990 s, it was also similar, between around 40 - 49\% in Delhi, Madhya Pradesh, Tamil Nadu and Uttar Pradesh. By the early 2000s however, in Uttar Pradesh and in (20 states of) India, the ratio of private to government teachers' salary had fallen to $20 \%$, i.e. private school teachers were paid, on average, only one-fifth of the pay levels of government school teachers. This was largely the result of the implementation of the Fifth Pay Commission recommendations, which greatly raised the bureaucraticallyset teacher salaries in govt-funded schools, but did not impact private school 
teachers' salaries. In Table 15, Kingdon and Banerji found that by 2008, private school teacher salaries constituted only $8 \%$ of govt. school regular teachers' salaries, in Bihar and Uttar Pradesh.

After implementation of the recommendations of the Sixth Pay Commission in 2009, government school teachers' salaries roughly doubled in one go (see Kingdon, 2010) and, again, private school teachers' market-determined salaries saw only incremental change. Thus, by 2014, Antony \& Chaudhury (2014) report that in rural Punjab, mean private school teacher salary was Rs. 1925 per month and we know from Ramachandran (2015) - as reported in Table 13 above - that average govt. primary school teacher salary in rural Punjab in 2014 was Rs. 59,654 per month, i.e. private school teachers pay was only about $3.2 \%$ of govt. school teachers' pay!

How can private schools can pay salaries that are this much lower than government school salaries? The reason is that whereas government teachers' pay is a bureaucratically-set high 'minimum wage', which may also be influenced by political pulls and pressures and be responsive to lobbying by strong government school teacher unions, private schools generally pay their teachers the market-determined wage i.e. the wage level determined by the demand and supply of educated persons in the labour market which is characterised by an excess supply of graduates; the 10.5 per cent graduate unemployment rate in India means that many unemployed graduates are willing to take teaching jobs at low salaries in private schools, and private schools take advantage of this low market-clearing wage.

To summarise, the fact that govt. school teachers are 4 to 8 times higher paid in India than in China and other countries suggests that in India, teachers must be drawn from a much higher part of the ability distribution in the population than in China and the other countries shown in Table 14. But this leads to the puzzle as to why, if teachers are substantially more able in India than in other countries, did Indian students do much worse than, for example, Chinese children in the international PISA standardized test of reading, mathematics, science, where China came $2^{\text {nd }}$ and India came 73rd, out of 74 countries. Similarly, if public school teachers are paid twelve to thirty times higher than private school teachers (since 2008) as shown in Table 15, one would expect that the quality of teaching and thus children's learning outcomes would be better in public than in private schools, but it is not so. The next section of the paper compares the relative learning achievement levels of children in private and public schools. 
Table 12

Actual take home salaries of govt. school regular teachers, by state

(Rupees per month)

\begin{tabular}{|c|c|c|c|c|c|c|}
\hline \multirow[t]{2}{*}{ State } & \multicolumn{3}{|c|}{ Primary } & \multicolumn{3}{|c|}{ Secondary } \\
\hline & $\begin{array}{c}\text { Salary of } \\
\text { new } \\
\text { appointee }\end{array}$ & $\begin{array}{c}\text { Salary } \\
\text { after } 15 \\
\text { years }\end{array}$ & $\begin{array}{c}\text { Salary } \\
\text { after } 25 \\
\text { years }\end{array}$ & $\begin{array}{c}\text { Salary of } \\
\text { new } \\
\text { appointee }\end{array}$ & $\begin{array}{c}\text { Salary } \\
\text { after } 15 \\
\text { years }\end{array}$ & $\begin{array}{c}\text { Salary } \\
\text { after } 25 \\
\text { years }\end{array}$ \\
\hline Tamil Nadu & 15,345 & 28,660 & 50,140 & 26,370 & 48,750 & 84,410 \\
\hline Karnataka (R) & 18,794 & 26,098 & 33,672 & 24,272 & 34,618 & 44,762 \\
\hline Karnataka (U) & 21,814 & 30,198 & 38,892 & 28,102 & 39,978 & 51,622 \\
\hline Jharkhand (R) & 28,650 & 39,780 & 44,400 & 37,494 & 57,523 & 78,637 \\
\hline Jharkhand (U) & 31,600 & 43,260 & 48,100 & 39,208 & 60,160 & 82,247 \\
\hline Odisha & 14,031 & 26,659 & 27,347 & 25,625 & 37,806 & 43,034 \\
\hline Rajasthan & 26,013 & -- & -- & 28,331 & -- & -- \\
\hline Mizoram & 16,504 & -- & -- & -- & -- & -- \\
\hline Uttar Pradesh & 29,293 & 39,683 & 44,783 & 37,226 & 47,716 & 52,996 \\
\hline Punjab (R) & 35,936 & 59,113 & 79,288 & 40,602 & 66,868 & 89,699 \\
\hline Punjab (U) & 36,588 & 60,194 & 80,742 & 41340 & 68,092 & 91,346 \\
\hline Simple Average & 25,922 & 40,623 & 49,653 & 33,578 & $\mathbf{5 1 , 5 9 5}$ & 66,793 \\
\hline
\end{tabular}

Source: Ramachandran (2015) at the National University of Educational Planning and Administration (NUEPA).

Note: R - Rural; U - Urban. Actual take home salary includes basic pay, grade pay, dearness allowance, House Rent Allowance (HRA), City Compensatory Allowance (CCA), and other benefits and deductions (if any).

\section{Table 13}

Govt. primary school teachers' mean salary as a multiple of state per capita GDP, 2014-15

\begin{tabular}{|c|c|c|c|c|c|c|c|}
\hline \multirow[b]{2}{*}{ State } & \multicolumn{2}{|c|}{ Govt. Primary school } & \multicolumn{2}{|c|}{ Govt. Junior school } & \multirow[b]{2}{*}{$\begin{array}{c}\text { State } \\
\text { Domestic } \\
\text { Product } \\
\text { per capita } \\
(\mathbf{2 0 1 4 - 1 5 )}\end{array}$} & \multirow{2}{*}{$\begin{array}{c}\text { Primary } \\
\text { teacher } \\
\text { salary as a } \\
\text { multiple of } \\
\text { state per } \\
\text { capita } \\
\text { income } \\
\end{array}$} & \multirow{2}{*}{$\begin{array}{c}\text { Junior } \\
\text { teacher } \\
\text { salary as a } \\
\text { multiple of } \\
\text { state per } \\
\text { capita } \\
\text { income }\end{array}$} \\
\hline & $\begin{array}{c}\text { Take home } \\
\text { salary } \\
\text { per month } \\
\text { July } 2014\end{array}$ & $\begin{array}{c}\text { Take home } \\
\text { salary } \\
\text { per annum } \\
\text { July } 2014\end{array}$ & $\begin{array}{c}\text { Take home } \\
\text { salary } \\
\text { per month } \\
\text { July } 2014\end{array}$ & \begin{tabular}{|} 
Take home \\
salary \\
per annum \\
July 2014
\end{tabular} & & & \\
\hline & (a) & (b) & (c) & (d) & (e) & $(f)=b / e$ & $(g)=d / e$ \\
\hline Tamil Nadu & 28,660 & 343920 & 48,750 & 585000 & 128366 & 2.7 & 4.6 \\
\hline Karnataka & 28,148 & 337776 & 37,298 & 447576 & 101594 & 3.3 & 4.4 \\
\hline Jharkhand & 41,520 & 498240 & 58,842 & 706104 & 52147 & 9.6 & 13.5 \\
\hline Odisha & 26,659 & 319908 & 37,806 & 453672 & 59229 & 5.4 & 7.7 \\
\hline Uttar Pradesh & 39,683 & 476196 & 47,716 & 572592 & 40373 & 11.8 & 14.2 \\
\hline Punjab & 59,654 & 715848 & 67,480 & 809760 & 99578 & 7.2 & 8.1 \\
\hline Simple mean & & & & & & 6.7 & 8.7 \\
\hline
\end{tabular}

Source: For teacher salary data, Table 6.3 in Vimala Ramachandran, 2015, NUEPA. We have taken teacher salary after 15 years' experience as the 'mean teacher salary'. For state per capita SDP, Ministry of Statistics and Programme Implementation, see http://statisticstimes.com/economy/gdp-capita-of-indian-states.php accessed on 27 Nov 2015. 
Table 14

Estimates of primary-school teacher salaries as a multiple of per capita GDP

\begin{tabular}{|l|c|c|c|}
\hline Country / state & Reference year & \multicolumn{2}{|c|}{ Estimated ratio of teacher salary to: } \\
\hline & & Per capita GDP & Per capita SDP \\
\hline OECD average & 2009 & 1.2 & -- \\
\hline Asian countries & & & -9 \\
\hline China & 2000 & 0.5 & -- \\
\hline Indonesia & 2009 & 1.5 & -- \\
\hline Japan & 2009 & $\sim 1.0$ & -- \\
\hline Bangladesh & 2012 & $\sim 1.9$ & -- \\
\hline Pakistan & 2012 & & 4.9 \\
\hline India & & 3.0 & 15.4 \\
\hline Nine Indian states & $2004-5$ & 6.4 & 17.5 \\
\hline Uttar Pradesh & 2006 & 5.9 & 7.2 \\
\hline Bihar & 2012 & 4.6 & \\
\hline Chhattisgarh & 2012 & & \\
\hline
\end{tabular}

Source: Table 5.4 in Chapter 5 of Dreze, Jean and Amartya Sen (2013) "An Uncertain Glory: India and its Contradictions". Allen Lane, London. 
Table 15

Teacher salary in private unaided (PUA) schools as a percentage of teacher salary in govt. and aided schools, various years

\begin{tabular}{|c|c|c|c|c|c|c|c|c|c|c|}
\hline & $\begin{array}{l}\text { Jain } \\
(\mathbf{1 9 8 8})\end{array}$ & $\begin{array}{l}\text { Kansal } \\
(1990)\end{array}$ & $\begin{array}{c}\text { Govinda \& } \\
\text { Varghese } \\
(1993)\end{array}$ & $\begin{array}{l}\text { Bashir } \\
\text { (1994) }\end{array}$ & $\begin{array}{c}\text { Kingdon } \\
\text { (1994) }\end{array}$ & $\begin{array}{l}\text { Singh \& } \\
\text { Sridhar } \\
(2002)\end{array}$ & $\begin{array}{c}\text { Muralidharan } \\
\text { \& Kremer } \\
\text { (2006) }\end{array}$ & $\begin{array}{l}\text { Kingdon \& } \\
\text { Banerji } \\
(\mathbf{2 0 0 8 )}\end{array}$ & $\begin{array}{c}\text { Goyal and } \\
\text { Pandey (2009) }\end{array}$ & $\begin{array}{l}\text { Antony \& } \\
\text { Chaudhury } \\
(2014)\end{array}$ \\
\hline & $\begin{array}{l}\text { Baroda } \\
\text { district, } \\
\text { Gujarat }\end{array}$ & $\begin{array}{c}\text { City of } \\
\text { New Delhi }\end{array}$ & $\begin{array}{l}5 \text { districts of } \\
\text { Madhya } \\
\text { Pradesh }\end{array}$ & \begin{tabular}{|c|} 
Many \\
districts of \\
Tamil Nadu
\end{tabular} & $\begin{array}{l}\text { Lucknow } \\
\text { district, } \\
\text { Uttar Pradesh }\end{array}$ & \begin{tabular}{|c|}
2 districts \\
of Uttar Pradesh
\end{tabular} & $\begin{array}{l}20 \text { states } \\
\text { of India }\end{array}$ & $\begin{array}{c}11 \text { districts of } \\
\text { Bihar \& UP } \\
\text { (data Jan 2008) }\end{array}$ & $\begin{array}{c}12 \text { districts of } \\
\text { Madhya Pradesh } \\
\text { \& Uttar Pradesh } \\
\text { (data Jan. 2007) }\end{array}$ & $\begin{array}{c}2 \text { districts } \\
\text { (Barnala \& Mansa) } \\
\text { of Punjab }\end{array}$ \\
\hline $\begin{array}{l}\text { No. of private school } \\
\text { teachers sampled }\end{array}$ & NA & 233 & 111 & 419 & 182 & 467 & NA & 734 & 1103 & 612 \\
\hline $\begin{array}{l}\text { Private pay as a } \\
\text { proportion of govt. } \\
\text { teacher pay }\end{array}$ & 0.47 & 0.39 & 0.49 & 0.47 & 0.42 & 0.20 & 0.20 & 0.08 & 0.08 & 0.03 \\
\hline $\begin{array}{l}\text { Govt. school teacher } \\
\text { pay as multiple of } \\
\text { private pay }\end{array}$ & 2.1 & 2.6 & 2.0 & 2.1 & 2.4 & 5.0 & 5.0 & 12.5 & 12.5 & 33.3 \\
\hline $\begin{array}{l}\text { Private pay as a \% of } \\
\text { aided salary }\end{array}$ & - & 39 & 66 & 50 & 43 & - & - & - & & - \\
\hline
\end{tabular}

Source: Jain (1988); Kansal (1990); Govinda \& Varghese (1993); Kingdon (1994); Bashir (1994); Singh \& Sridhar (2002); Muralidharan and Kremer (2008); Goyal and Pandey (2010); Kingdon \& Banerji (2008); Antony \& Chaudhuri (2014). 


\section{Learning outcomes in private schools}

While the National Council of Educational Research and Training, New Delhi (NCERT) has been carrying out large-scale surveys of children's learning achievement levels using Item Response Theory since 2011, it conducts these only in public schools. Fortunately, it is possible to compare achievement levels in govt. and private schools in the surveys carried out for the Annual Status of Education Report (ASER, various years). Table 16 based on ASER data shows that while children's learning levels in both private and public schools are low, they are higher in private than public schools.

The ASER report presents only raw learning achievement data but, since private school students typically come from better-off and more educated homes, their achievement levels would be expected to be higher even if private schools were of no better quality than public schools. Thus comparing raw learning levels in private and public schools could lead to a potentially false inference that private schools are higher quality.

Luckily, there is quite sophisticated evidence in India which compares learning levels in the two types of schools after statistically controlling for the socio-economic background of the children studying in private and public schools. The different authors have used a variety of data sources, e.g. the National Human Development Survey, the ASER survey, Young Lives survey and surveys in particular states or districts that the authors themselves conducted. The published literature published uses either simple regression analysis (Tooley and Dixon, 2005; Wadhwa, 2014), or use a variety of elaborate econometric techniques to correct for the problems of 'selectivity' and 'endogeneity', namely the problem that more able or more motivated students may self-select into private schools, techniques such as household fixed effects, village fixed effects, propensity score matching methods, panel data approach and randomised control trials. These studies are by Kingdon (1996), Desai et al (2008), Goyal (2009), French and Kingdon (2010), Chudgar and Quin (2012), Muralidharan and Sundararaman (2013), Singh (2015) and Azam et. al. (2016). This evidence shows that when students' home background is controlled for, the large raw learning-gap between private and public schools falls but, in most studies, it does not disappear: typically an achievement advantage of 0.10 to 0.35 standard deviations remains. This literature indicates that children's learning levels in private schools are no worse than, and in many studies better than, those in government schools, after controlling rigorously for the differing home backgrounds of the children in these two types of school.

The next section puts this evidence (on the relative effectiveness of public and private schools) together with evidence on the unit costs of private and public schools, to examine the 'value for money' (VFM) offered to fee-paying parents by private schools and the VFM that accrues from public expenditure on education.

\section{Value for Money from private schools}

A study by Kingdon et. al. (2016) puts the ASER evidence on learning levels of students in public and private schools together with the evidence on per pupil 
expenditure (PPE) in public and private schools in eight major states of India, to examine the 'value for money' offered by public and private schools. Table 17 shows the value for money (VFM) calculation ${ }^{12}$. While there is much inter-state variation, we illustrate the findings by looking at the example of Madhya Pradesh. Table 17 shows that annual PPE in public schools in Madhya Pradesh was Rupees 9384 and PPE in private schools was Rupees 3700 per annum, and thus the public : private PPE ratio was 2.5:1 (see row ' $g$ ') i.e. public schools operated at 2.5 times the perpupil-expenditure of private schools. It also shows that the ratio of public to private students' reading achievement levels was $0.48: 1$, i.e. public schools produced only $48 \%$ as much learning as private schools. Putting these two things together we find that private schools offer 5.3 times the value for money (VFM) as public schools in Madhya Pradesh. The findings are very similar for Kerala. However, there is much variation across the states. While in Bihar, Tamil Nadu, Punjab and Orissa, private schools are roughly twice as cost-effective (offer twice as much VFM) as public schools, in Gujarat, private schools offer 12 times as much VFM as public schools, and Uttar Pradesh is an outlier, with private schools there offering 29 times as much VFM as public schools - which is largely due to the very low fee levels of private schools in Uttar Pradesh, as also seen earlier in Tables 8 to 11 . Kingdon et. al. (2016) also present VFM calculations using numeracy achievement levels in private and public schools and the results there are even starker, though they are not presented here for space reasons.

Change over time in the 'cost per unit of learning' in govt. schools can also be seen in the last column of Annex Table 2. This shows that the cost per learning unit has roughly trebled in govt. schools in just the 6 year period between 2010 and 2016 . This is a product of both falling learning achievement levels and strongly rising teacher salaries in govt. schools, which the table shows increased by over 15 percent per annum in the period 2008 to 2017 (the period from just before the Sixth Pay Commission to just after the Seventh Pay Commission), or increased by $8.5 \%$ per annum, if we take just the period from 2010 to 2016.

\section{The Right to Education Act and its provision of Public Private Partnership}

The high value for money offered by private schools is probably what led to the adoption of a kind of public private partnership (PPP) in India's Right to Education (RTE) Act 2009, with government funding and private schools producing education.

While India at the time of Independence already had an extensive PPP in education, namely the aided school system of privately managed schools funded by government, in fact, the aided schools, over time, due to centralising legislation in the early 1970s (discussed in Section 2 and footnote 3) have become virtually like govt. schools. Now, like govt. schools:

(i) they have little autonomy, since a government-appointed Service Commission recruits their teachers, and they have to charge govt. prescribed (nil) fee;

\footnotetext{
${ }^{12}$ The govt. school PPE calculated for these eight states differs from the estimates of Dongre and Kapur (2016), but the latter calculated PPE for govt. and aided schools. Also see Annex 1 which discusses the reasons why Dongre \& Kapur's PPE estimates are significantly lower than the true estimates.
} 
(ii) they face no competition for survival since they have guaranteed state funding, de facto irrespective of any decline in their number of students;

(iii) they are not very accountable to parents since their funding is secure irrespective of whether parents like/patronise them or not.

(iv) their teachers are not very accountable to their private management boards since their salaries are paid directly into their bank accounts from the government treasury.

However, whether PPP will solve the problems of education is thought to depend on the extent to which the system exemplifies autonomy, freedom from bureaucratic control, inter-school competition, and accountability towards parents.

Perhaps that is why the Right to Education (RTE) Act 2009 brought in a new form of PPP whereby private schools (all of which are obliged to give at least $25 \%$ of their seats to disadvantaged children) get a per-student reimbursement from government. This form of PPP represents a per student grant and it effectively sets up inherently stronger incentives for schools to keep parents satisfied and give good quality education, since they would lose public funding if a child left to join another school.

However, newspaper reports nationally as well as the author's interviews with representatives of associations of private schools (National Independent Schools Alliance; Independent Schools Federation of India; Society for the Unaided Private Schools of Rajasthan, etc.) indicate that private schools, especially the high fee ones, have been resisting this form of PPP because of two major factors:

(i) firstly because state governments are mostly reimbursing them only a fraction of the amount mandated by section 12(2) of the RTE Act, and in many cases with delays of more than two years, without any compensation for delays ${ }^{13}$.

(ii) Secondly, many private schools fear corruption in official release of reimbursements and fear that, by accepting public money, they will come under the purview of the Right to Information Act and can be harassed, blackmailed and subjected to extortion by unscrupulous persons on the grounds that they do not fulfil some rule or another, from among a large number of rules, many of which are perceived to be impractical or which are mutually incompatible with other rules ${ }^{14}$.

\footnotetext{
${ }^{13}$ When a school run by the Urn Education Society in Mumbai went to court against a threat by the state government to shut it down due to its refusal to admit more children for free under the RTE Act because the Maharashtra state govt. had not paid the school a reimbursement of Rs. 50 lakh (approx. Rs. 5 million) for three years, in a judgment given out on $5^{\text {th }}$ December 2016, the Bombay High Court was unsympathetic, ordering the school to admit more children forthwith, irrespective of the large backlog of non-payment of reimbursement by the govt. See http://indianexpress.com/article/education/admit-rte-kids-school-not-a-money-making-venturebombay-hc-4412651/ (accessed on 6 Dec. 2016)

14 To take one example, RTE Rules say that to gain government recognition, a school must be compliant with the National Building Code, i.e. be made with iron-reinforced concrete. In focus group discussions with this author, many small private schools from rural parts of Uttar Pradesh claimed that this rule is used of extort bribes from them, while most govt. schools do not comply with this norm. To take another example from Uttar Pradesh, the recognition rule notified in a Govt. Order dated 8 May 2013 that a private school cannot raise its tuition fee by more than $10 \%$ once every three years, is mutually incompatible with another pre-existing UP govt. rule from 1991 that in order to get a 'No Objection Certificate' of the Govt. of UP, the school has to pay the govt.-prescribed salaries to teachers, which typically rise by about $10 \%$ per annum. No school can comply with both these rules at the same time. There are many examples of thoughtless rules and there is anecdotal
} 
Some groups ${ }^{15}$ have suggested that a way to overcome this conundrum is for government to fund private schools in this type of PPP by giving the per-child subsidy to parents as a voucher or 'Direct Benefit Transfer' which the parents can then use at a private school of their choice. Moreover, instead of paying for only a small proportion of disadvantaged children to attend (25\% of seats in) private schools, all disadvantaged children could potentially be given school choice funded by vouchers. However, this idea has not been seriously considered.

One frequent criticism of the PPP provision of the RTE Act 2009 is that it allows only a fraction of the poor and disadvantaged children to attend private schools. As per National Sample Survey (NSS, 2014-15) data, 30\% of children aged 6-14 in India study in private unaided schools, so $25 \%$ or a quarter of their total capacity comes to 7.5 percent. That is, the RTE Act guarantees for $7.5 \%$ of children to study in private schools under 'free and compulsory education', not even for all poor/disadvantaged children, let alone for all children. The children designated in the RTE Rules as 'disadvantaged' (Schedule Caste, Schedule Tribe and Other Backward Caste children) alone constitute nearly $70 \%$ of the children in the country. Together with 'economically weaker section' children, the proportion of poor and disadvantaged children comes to easily more than $80 \%$ children of the country, but RTE provision for attendance in private schools is only for $7.5 \%$ of the children, i.e. this benefit of the RTE Act is available to less than $10 \%$ of the eligible children. Given the large demand for few private school seats, applicant children are selected for private schools on the basis of a lottery, which is also seen to raise some ethical issues.

There is another source of resistance to the RTE Act from private schools. The lowfee private schools and their associations (for example, NISA ${ }^{16}$ ) have objected to sections 18 and 19 of the RTE Act that impinge on them adversely. Section 18 stipulates that private schools cannot be established or continue to function without obtaining a 'certificate of recognition' from the state government, though it does not decree the same for government schools. Section 19 taken together with the Schedule of the RTE Act, lays down the conditions a private school has to fulfil (maximum pupil-teacher-ratio norms and infrastructure norms) in order to gain government recognition, and it also specifies the penalties for violation of the recognition conditions. Many state governments have added other conditions ${ }^{17}$.

While section $8(\mathrm{~g})$ of the Act states that government schools shall also conform to the norms of the Schedule, they are not obliged to obtain a certificate of recognition and are not subject to penalties for non-compliance with the recognition conditions. Official DISE data show that a good proportion of government schools do not fulfil many of the recognition conditions ${ }^{18}$, but no notices are given to these schools to

evidence that some unscrupulous persons, by threatening to use the Right to Information Act 2005, exploit these lacunae in the rules to demand bribes from private schools.

${ }^{15}$ E.g. the Think Tank Centre for Civil Society and the National Independent Schools Alliance (NISA).

${ }^{16}$ National Independent Schools Alliance is an association of state level associations of private schools in India.

${ }^{17}$ E.g., in Uttar Pradesh, a Government Order dated 13 May 2013 notifies about 40 different conditions a private school has to fulfil in order to gain recognition.

${ }^{18}$ In reply to a parliamentary question, the Ministry for Human Resource Development stated that only $6.4 \%$ of govt. schools in the country fulfil the recognition norms. See (accessed on 15 Jan. 2017)

http://www.newindianexpress.com/magazine/voices/2017/jan/14/six-years-on-only-64-of-govt-schools-complywith-rte-norms-1559014.html 
shut down, but private schools that cannot fulfil the same norms are given closure notices. Data collated from the public domain by NISA on school closures due to the RTE Act, show that as of October 2016, 9382 private schools had received closure threat, another 7898 private schools had received actual closure notices, and a further 3332 private schools had actually closed down, (http://nisaindia.org/data-onschool-closures), based on data available from only a few states, e.g., data on actual school closures from government documents is available only from three states ${ }^{19}$.

An important recognition norm specified in the state rules of the RTE Act 2009 is that the school must be a registered society, not run for private gain or profit. This stricture inconveniences the vast majority of private schools, which are low-fee and which run for the livelihoods of their founding entrepreneurs, and is also objectionable to many high-fee private school founders who seek a return on their investment. While it is likely that a small proportion of the roughly 300,000 recognised private schools in the country are run by benefactors and philanthropists who give land, buildings, furniture, etc. as charity, without expectation of profit, it is unlikely to be true of the large bulk of private schools. This impractical recognition condition renders probably most private schools illegal, while creating the myth that private schooling in India is mostly charitable in nature.

In resisting sections 18 and 19 of the RTE Act 2009, the private school associations also allege that apart from being expensive and impractical, many of the recognition norms of the RTE Act prescribed for schools are not evidence based, for example, they cite research showing that a pupil teacher ratio below 30 does not consistently lead to higher student learning. Similarly, while they say it is desirable that schools have furniture for children and have a separate office room for clerical staff, boundary wall, etc., these are not necessary in order to produce good learning outcomes, and should not become the reason for closing down the lowest-fee rural private schools. In short, they state that an Act which avows to guarantee children's right to education should not paradoxically become a means to violate that right due to school closures, in the name of some infrastructure and input norms which have no proven connection with schooling quality; instead, they argue for school recognition based on the learning levels of the school's pupils. At the time of writing this article, National Education Policy is under formulation and India's HRD ministry has announced that it will amend the RTE Act to include learning levels of students as a recognition norm.

\section{Conclusions}

This paper has sought to bring together evidence on Indian private schools in one convenient place. It has some surprising and some policy-relevant findings.

\footnotetext{
${ }^{19}$ A scan of newspaper reports of Uttar Pradesh in 2015-16 by the author showed that 960 private unrecognised schools were either given closure notice or were actually closed down in this one year alone. In Lucknow district, in 2015, a total of 258 schools were given show-cause notices to close down, due to not having govt. recognition. The author also sent queries to district education officials of all 75 districts of UP, under the Right to Information (RTI) Act, and 9 district officials replied. This revealed that in 2016, in these nine districts (Etawah, Lakhimpur Kheri, Chitrakoot, Moradabad, Faizabad, Fatehpur, Lalitpur, and Baghpat), 255 unrecognised schools were given closure notice and 78 were actually closed down.
} 
The paper shows a rapid migration of students towards private schools, and an emptying of government schools. The out-migration from govt. schools has rendered a high proportion of them economically unviable, with very high 'per pupil expenditures', yielding low value-for-money from public education expenditure, to the extent that three states (Rajasthan, Maharashtra and Chhattisgarh) recently closed down nearly 24,000 government schools. The abandonment of govt. schools is a longer term trend visible in DISE data from 2005, yet education policy and legislation has been ignoring this trend. For example, section 6 of the RTE Act 2009 legally obligates States to create more govt. schools - the kind the public has been deserting. An important policy lesson therefore is that decision-takers must take evidence into account before making education policy or legislation.

The paper discovered that a major reason for the rapid growth of private schools is their affordability. Data showed that the vast bulk of private schools in India are 'low' fee schools, when benchmarked against the state per capita income and daily wagers' incomes. From a policy maker's angle, the fact that about $80 \%$ of private schools' fee levels are lower than government schools' per pupil expenditure, draws attention to the serious difficulty that such low-fee private schools must face in mustering the resources to comply with the infrastructure norms of the Right to Education (RTE) Act 2009 without public subsidy, when most of the (well-funded) government schools themselves cannot comply with these norms; not surprisingly perhaps, data suggested that many private schools have been compelled to close down due to such non-compliance. It is clearly useful if policy on how to utilise, support and regulate private schools can take into account these realities, in order to avoid unintended counterproductive effects such as the closure of the low-fee private schools which may be successfully imparting learning but which lack the resources to fulfil the demanding infrastructure and other conditions of government recognition.

The third major finding in the paper is that private schools are able to run on low fee - or low per-student-cost compared to govt. schools - mainly because their teacher salaries are a small fraction of the salaries in government schools. Government teacher salaries in India are high not only in relation to private schools but also compared with those in other countries. Despite being paid at least four times the salaries of teachers in China (in terms of multiples of their respective per capita incomes), Indian teachers' performance - judged from the learning levels of their students - has been very poor in the international PISA test, with India ranking $73^{\text {rd }}$ and China ranking $2^{\text {nd }}$, out of 74 countries. This suggests the need to link future teacher salary increases to the degree of teachers' acceptance of greater accountability, rather than across-the-board increases irrespective of performance or accountability. The paper discussed some ways of increasing accountability.

The discussion on the Right to Education Act 2009 suggests that the higher-fee private schools resist the RTE Act firstly because of their fear of loss of autonomy and the potential to be blackmailed under the Right to Information Act 2005 if they accept government reimbursement money and, secondly, the very low rate of reimbursement per child by the state governments for educating poor and disadvantaged students, a rate much below the amount stipulated in the RTE Act. It shows that many low fee private schools are unable to comply with the expensive 'recognition' conditions, leading to their being closed down or threatened to be closed-down by the education authorities. 
The significantly higher value-for-money offered to parents by private schools compared to the value for money from public expenditure on government schools suggests that a public private partnership (PPP) model would be useful, whereby the public sector funds but the private sector produces education. However, there are scores of different designs of PPPs within each of the broad types (voucher schemes, Charter schools, Concession schools) in different countries - each with its own inherent in-built incentive structures for the schools and teachers. Before choosing any particular form of educational PPP, India must study these different designs and their relevance/applicability/adaptability, and must also pilot test the chosen models before scaling up any novel interventions. As shown in section 8 above, there have been major implementation problems with the PPP legislated in India's Right to Education Act 2009 because the stipulated form of PPP was never pilot tested in a few districts and improved, before being enacted for the entire country and given legislative force.

It is hoped that this paper will assist in the formulation of more evidence-based education policy and legislation in India, rather than policy that may be formulated on hunch, ideology or expediency. The evidence presented here can assist decisiontakers to craft policy based on the realities of private and public schooling in India, rather than in the absence of the knowledge of these realities. 
Table 16

Learning achievement levels of children of Class $\mathrm{V}$ in public and private schools

\begin{tabular}{|c|c|c|c|c|c|c|}
\hline & \multicolumn{3}{|c|}{$\begin{array}{c}\text { \% children in Std. V who can } \\
\text { do division }\end{array}$} & \multicolumn{3}{c|}{$\begin{array}{c}\text { \% children in Std. V who can } \\
\text { read a Std. II level text }\end{array}$} \\
\hline & $\underline{\text { Public }}$ & $\underline{\text { Private }}$ & $\underline{\underline{\text { Difference }}}$ & $\underline{\underline{\text { Public }}}$ & $\underline{\text { Private }}$ & $\underline{\text { Difference }}$ \\
\hline 2010 & 33.9 & 44.2 & 10.3 & 50.7 & 64.2 & 13.5 \\
\hline 2011 & 24.5 & 37.7 & 13.2 & 43.8 & 62.7 & 18.9 \\
\hline 2012 & 20.3 & 37.8 & 17.5 & 41.7 & 61.2 & 19.5 \\
\hline 2013 & 20.8 & 38.9 & 18.1 & 41.1 & 63.3 & 22.2 \\
\hline 2014 & 20.7 & 39.3 & 18.6 & 42.2 & 62.5 & 20.3 \\
\hline
\end{tabular}

Source: ASER Trends over time. Pratham, 2015.

Table 17

Value for money from public expenditure on education in India

\begin{tabular}{|c|c|c|c|c|c|c|c|c|c|}
\hline $\begin{array}{l}\text { S. } \\
\text { No. }\end{array}$ & Variables & $\begin{array}{r}\text { Uttar } \\
\text { Pradesh }\end{array}$ & Bihar & Gujarat & $\begin{array}{l}\text { Tamil } \\
\text { Nadu }\end{array}$ & $\begin{array}{l}\text { Madhya } \\
\text { Pradesh }\end{array}$ & Kerala & Punjab & Odisha \\
\hline a. & $\begin{array}{l}\text { Govt. Per Pupil Expenditure } \\
\text { (Rupees) }\end{array}$ & 23012 & 3105 & 47044 & 33126 & 9384 & 39267 & 16166 & 8897 \\
\hline b. & Govt Achievement (Reading) & 27 & 45 & 45 & 50 & 28 & 61 & 61 & 50 \\
\hline c. & $\begin{array}{l}\text { Govt Expenditure per } \\
\text { Achievement Unit (Rupees) } \\
(\mathbf{c}=\mathbf{a} / \mathbf{b})\end{array}$ & 859 & 70 & 1055 & 664 & 338 & 641 & 265 & 178 \\
\hline d. & $\begin{array}{l}\text { Private Per Pupil } \\
\text { Expenditure (Rupees) }\end{array}$ & 1800 & 4200 & 5400 & 10800 & 3700 & 8400 & 7900 & 7150 \\
\hline e. & $\begin{array}{l}\text { Private Achievement } \\
\text { (Reading) }\end{array}$ & 61 & 88 & 64 & 40 & 58 & 71 & 74 & 77 \\
\hline f. & $\begin{array}{l}\text { Private Expenditure per } \\
\text { Achievement Unit (Rupees) } \\
(\mathbf{f}=\mathrm{d} / \mathrm{e})\end{array}$ & 29 & 48 & 84 & 269 & 63 & 119 & 107 & 93 \\
\hline g. & $\begin{array}{l}\text { Govt./ Private Per Pupil } \\
\text { Expenditure Ratio }(\mathrm{g}=\mathrm{a} / \mathrm{d})\end{array}$ & 12.8 & 0.7 & 8.7 & 3.1 & 2.5 & 4.7 & 2.0 & 1.2 \\
\hline h. & $\begin{array}{l}\text { Govt./ Private Numeracy } \\
\text { Ratio }(\mathrm{g}=\mathrm{b} / \mathrm{e})\end{array}$ & 0.44 & 0.51 & 0.70 & 1.24 & 0.48 & 0.87 & 0.83 & 0.65 \\
\hline i. & $\begin{array}{l}\text { Private/Govt. Efficiency } \\
\text { Ratio ( } \mathbf{i}=\mathbf{c} / \mathbf{f} \text { ) }\end{array}$ & 29.3 & 1.5 & 12.5 & 2.5 & 5.3 & 5.4 & 2.5 & 1.9 \\
\hline
\end{tabular}

Note: PPE in public schools in each state is calculated by taking the total elementary education expenditure of the state plus central government's expenditure in the state on Sarva Shiksha Abhiyan inputs (such as free uniforms, textbooks, cash scholarships, school improvement grants etc. but not on the mid-day meals) for 201415 , and dividing this total public expenditure by the number of students enrolled in government elementary schools within the state, as taken from the District Information System on Education (DISE) data for 2014-15. These PPE estimates cannot be compared with those in Dongre and Kapur (2016) for a variety of reasons, several of which are set out in Annex 1. 


\section{References}

Antony, Meril and Chaudhuri, Nilanjan (2014) "Limiting Choices and Denying Opportunities? The Case of School Closures in Punjab". New Delhi: Centre for Civil Society, 2014.

Azam, M., G. Kingdon and K. B. Wu. "The Impact of Private Secondary Schooling on Cognitive Skills: Evidence from India", Education Economics, 24(5), pp 465480, 2016.

ASER (various years) Annual Status of Education Report, ASER Centre, Pratham, New Delhi.

Bashir, Sajitha (1994) Public versus Private in Primary Education: Comparisons of School Effectiveness and Costs in Tamil Nadu, Unpublished Ph.D. thesis, London School of Economics.

Chudgar, Amita and Elizabeth Quin (2012) "Relationship between private schooling and achievement: Results from rural and urban India", Economics of Education Review, 31(4), p 376-90. August.

Desai, Sonalde, et. al. (2008) Desai, S., Dubey, A., Vanneman, R., and Banerji, R. (2008), Private Schooling in India: A New Educational Landscape, India Human Development Survey, Working Paper No. 11.

Dongre, Ambrish and Avani Kapur (2016) "Trends in Public Expenditure on Elementary Education in India", Economic and Political Weekly. Vol. 51, Issue No. 39, 24 Sep, 2016.

Dréze, Jean and Amartya Sen (2013) "An Uncertain Glory: India and its Contradictions". Allen Lane, London.

French, R. and Kingdon, G. (2010) "The relative effectiveness of private and government schools in Rural India: Evidence from ASER data", Dept. of Quantitative Social Science Working paper, 10-03. Institute of Education, University of London.

Goyal, Sangeeta (2009) "Inside the house of learning: the relative performance of public and private schools in Orissa", Education Economics, 17(3): p.315-27. August.

Goyal, Sangeeta and Priyanka Pandey (2010) "How do Government and Private Schools Differ? Findings from two large Indian states", South Asia Human Development, World Bank, Washington D.C.

Govinda, R. and N.V. Varghese (1993) Quality of Primary Schooling in India: A Case Study of Madhya Pradesh, Paris: International Institute for Educational Planning, and New Delhi: National Institute of Educational Planning and Administration (NIEPA). 
IMRB Surveys 2009 and 2014 Commissioned by the Ministry of Human Resource Development.

Jain, S. C. (1988) "Non-official Initiatives for Catering to the Educational Needs of the Urban Poor: A Case Study of Baroda Slums", Unpublished typescript, Baroda: Baroda Citizens Council.

Kansal, S. M. (1990) "Disparity in Income and Levels of Living Among Teachers in Delhi", Economic and Political Weekly, 25 No. 46, 17th November: 25472554.

Kingdon, G.G. (1996), "The Quality and Efficiency of Public and Private education: A case study of Urban India", Oxford Bulletin of Economics and Statistics, 58 (1), 57--82.

Kingdon, G.G. (2007) "The Progress of School Education in India", Oxford Review of Economic Policy, 23, No. 2: 168-195, Summer 2007.

Kingdon, G.G. (2008), "School-Sector Effects on Student Achievement in India", in ed. Chakrabarti, R. and Petersen, P.: School choice international: Exploring public--private partnerships, chapter 6, Boston, MA: MIT Press.

Kingdon, G.G. (2010) "The Impact of the Sixth Pay Commission on Teacher Salaries in India", RECOUP Working Paper 29, Faculty of Education, University of Cambridge, May 2010.

Kingdon, Geeta G. (1994) An Economic Evaluation of School Management-types in India: A Case Study of Uttar Pradesh, Unpublished D.Phil. thesis, Economics Department, Oxford University.

Kingdon, G. and R. Banerji (2008) SchoolTELLS Survey of Bihar and Uttar Pradesh. Mimeo, Institute of Education, University College London.

Kingdon and Muzammil (2015) "Government per pupil expenditure in Uttar Pradesh: Implications for the reimbursement of private schools under the RTE Act", CSAE Working Paper WPS/2015-18, Department of Economics, University of Oxford.

Kingdon, G., S. Sinha and V. Kaul, with G. Bhargava \& K. Pental (2016). "Value for money from Public Education Expenditure on Elementary Education in India", Discussion Paper Series, Education Global Practice, South Asia Region, World Bank, New Delhi. April 2016.

Muralidharan, K. and Kremer, M. (2008), Public and Private Schools in Rural India, in ed. Chakrabarti, R. and Petersen, P.: School choice international: Exploring public--private partnerships, Boston, MA: MIT Press.

Muralidharan, K. and V. Sundararaman (2013) "The Aggregate Effect of School Choice: Evidence from a Two-stage Experiment in India", NBER Working Paper No. 19441. 
NSS (2014-15) National Sample Survey, National Sample Survey Organization. New Delhi.

Ramachandran, Vimala (2015) "Teachers in the Indian education system: Synthesis of a nine-state study", National University of Educational Planning and Administration, NUEPA, New Delhi. March 2015.

Singh, Abhijit (2015) "Private school effects in urban and rural India: Panel estimates at primary and secondary school ages", Journal of Development Economics, Vol. 113 C, pp. 16-32.

Singh, Shailendra and Kala Seetharam Sridhar (2002) "Government and Private Schools: Trends in Enrolment and Retention", Economic and Political Weekly, Vol. 37, No. 41, 12 October 2002.

Srivastava, Prachi (2013) "Low fee private schooling: Issues and Evidence", Chapter in P. Srivastava (Ed.), Low-fee Private Schooling: aggravating equity or mitigating disadvantage? Oxford Studies in Comparative Education Series. (Symposium Books, Oxford, 2013.)

Tooley, J. and Dixon, P. (2005), Private School is Good for the Poor: A Study of Private Schools Serving the Poor in Low-Income Countries, CATO Institute, Washington, DC.

Wadhwa, Wilima (2014) "Government vs private schools: Have things changed?", ASER Report. http://img.asercentre.org/docs/Publications/ASER\%20Reports/ASER\%202014 IArticles/wilimawadhwa.pdf 


\section{Annex 1 \\ Reasons why the per pupil expenditure (PPE) estimates in Dongre and Kapur (2016) are serious under-estimates of the actual PPE in the government school system}

Dongre and Kapur (2016) have made a pioneering contribution by estimating per pupil expenditure in govt-funded schools (government and aided schools) across the Indian states, and they have done it for two time-periods, 2011-12 and 2014-15 so they are also able to show the temporal trends in govt. funded schools' per pupil expenditure (PPE). They have relied on state budget documents for getting information on public education expenditure, and relied on the official District Information System on Education (DISE) for information on total elementary school enrolment in the different states. They have perforce had to live with the limitations of the state budget documents, in particular with the fact that different states follow somewhat different conventions, for example, whether to include in the state budget the Sarva Shiksha Abhiyan funds and the mid-day meal funds received from the central government.

The PPEs reported in Dongre and Kapur (2016) are likely to be great underestimates since :

1. They exclude public expenditure on govt. and aided school teachers' pension and gratuity. This is because the state budgets do not display teachers' pensions and gratuity under the 'elementary education' head. These expenses are lumped together with some other budget heads and not shown under education.

2. In many states, a high proportion of secondary schools include junior sections (classes 6, 7 and 8) and the govt. expenditure on these schools is in some states reflected in the secondary education budget, not in the elementary (or 'prathmik) education budget, whereas their enrolments till class 8 from DISE data have been included in the denominator of the PPE calculation.

3. Many states do not include funds for education received under the free midday-meal scheme or under Sarva Shiksha Abhiyan from the Central govt. in their State education budget (i.e. public expenditure on free uniforms, free text-books, cash scholarships to dalit pupils, or para-teacher salaries), for example, Uttar Pradesh, so these remain excluded.

4. In their denominator of the PPE calculation, the DISE enrolment data has been used without adjusting for the (anecdotally large) over-reporting of enrolment; emptying govt-funded schools have an incentive to over-report their total enrolment to justify teacher numbers, and also so that they can get a greater quantity of grains for mid-day meals, cloth for uniforms, and money for cash scholarship to dalit children.

5. Dongre and Kapur's estimates include expenditure on aided schools which the govt. may fund somewhat less than its own schools.

To take one example, Dongre and Kapur estimate the 2014-15 PPE in the govtfunded school system in Uttar Pradesh as Rs. 13,102 per annum (or Rs. 1092 per month), but the author's own estimate of the PPE in the govt. schools of UP for the same 2014-15 year (in Kingdon and Muzammil, 2015) was Rs. 23,004 pa or Rs. 1917 pm, i.e. 75\% higher than that estimated by Dongre and Kapur; after adjusting for inflated enrolment based on two different surveys of the extent of 
enrolment-inflation, the estimated PPE in govt. schools of UP was Rs. 2320 per month, or Rs. 27,840 pa.

Another study which estimates per pupil expenditures in the govt. school system is Kingdon, Sinha and Kaul (2016) which contains PPE estimates for 8 major states of India but, again, due to the method used for estimation, there are some significant differences between the govt. PPE estimates of Kingdon, Sinha and Kaul (2016) and Dongre and Kapur (2016); for one thing Kingdon et. al. estimate PPE in the govt. school system while Dongre and Kapur estimate PPE in the govt. and aided schools taken together, but there are several other reasons for the differences as well, some of which are listed above. Since Dongre and Kapur report PPE estimates for most Indian states using a single common methodology, we report those.

\section{Annex 2}

\section{The RTE Act and the reimbursement of private schools}

Under section 12(2) of the Right to Education Act 2009, state governments are meant to set an upper limit for their reimbursement to private schools for admitting poor children. This upper limit is mandated to equal to the amount of per pupil expenditure (PPE) that the government incurs in its own schools. In other words, state governments are meant to calculate the PPE in their govt. school system and then reimburse private schools at that rate, or reimburse the actual fee level of the school, whichever is the lower. However, to this author's knowledge, as of 2016, no Indian state government has actually made such a calculation of PPE in the govt. school system within the state and put such calculation in the public domain. Instead several states have declared an arbitrary amount they will reimburse to private schools, which is typically very significantly lower than the PPE in the govt. school system estimated by academic researchers. For example, in Uttarakhand, the government's reimbursement to private schools for educating poor children is fixed at Rs. 860 per month or Rs.10,320 per annum, but the 2014-15 PPE in the government-funded school system in the state was Rs. 26,236 pa (Dongre and Kapur, 2016), i.e. the reimbursement limit set by the Uttarakhand state govt. is only $40 \%$ of the govt. PPE on schools funded by it, i.e. govt. and aided schools.

The columns (i) and (j) of Table 9 showed the government reimbursement to private schools in the few states for which this information is available. It is clear that in states other than Delhi, between $66 \%$ and $93 \%$ of private-school pupils' fee is less than their respective state governments' reimbursement rate for private schools. And that is when the reimbursement rates set by the various states are a fraction of the actual govt. school PPE For example, in Uttarakhand, $71 \%$ of private school students' schools charge a fee that is lower than the govt. reimbursement limit of Rs. 860 per month, and this limit in turn is only about $40 \%$ of the actual PPE in the govt. school system. 
Annex Table 1

Number and percentage of primary-age children $(6-10$ year olds) who were Out of School in 2009 and 2014 (India and Uttar Pradesh)

\begin{tabular}{|l|r|r|r|r|r|r|}
\hline & \multicolumn{3}{|c|}{ India as a whole } & \multicolumn{2}{|c|}{ Uttar Pradesh } \\
\hline & $\begin{array}{r}\text { Population } \\
\text { of 6-10 } \\
\text { year olds }\end{array}$ & $\begin{array}{r}\text { Number } \\
\text { Out of } \\
\text { school }\end{array}$ & $\begin{array}{r}\text { \% } \\
\text { Out of } \\
\text { school }\end{array}$ & $\begin{array}{r}\text { Population } \\
\text { of 6-10 } \\
\text { year olds }\end{array}$ & $\begin{array}{r}\text { Number } \\
\text { Out of } \\
\text { school }\end{array}$ & $\begin{array}{r}\text { \% } \\
\text { Out of } \\
\text { school }\end{array}$ \\
\hline 2009 & $11,77,24,796$ & $43,43,702$ & 3.69 & $2,27,60,481$ & $15,98,992$ & 7.03 \\
\hline 2014 & $12,27,71,166$ & $33,98,338$ & 2.77 & $2,45,20,823$ & $9,40,164$ & 3.83 \\
\hline Abs. change & $50,46,370$ & $-9,45,364$ & -0.92 & $17,60,342$ & $-6,58,828$ & -3.8 \\
\hline$\%$ change & 4.30 & 21.80 & & 7.70 & 41.20 & \\
\hline
\end{tabular}

Source: IMRB Surveys 2009 and 2014 commissioned by the Ministry of Human Resource Development.

Annex Table 2

Starting salary of Primary and Junior teachers' in govt. schools

\begin{tabular}{|c|c|c|c|c|c|c|c|}
\hline Year & $\begin{array}{l}\text { Basic } \\
\text { Pay } \\
\text { (a) }\end{array}$ & $\begin{array}{l}\text { Dearness } \\
\text { Allowance } \\
\text { (DA) } \\
\text { (b) }\end{array}$ & $\begin{array}{c}\text { House Rent } \\
\text { Allowance } \\
\text { (HRA) } \\
\text { (c) }\end{array}$ & $\begin{array}{l}\text { City Compen. } \\
\text { Allowance } \\
\text { (CCA) } \\
\text { (d) }\end{array}$ & $\begin{array}{l}\text { Total Pay } \\
\text { (Rs. per } \\
\text { month) } \\
\text { (e) }\end{array}$ & $\begin{array}{l}\text { Learning } \\
\text { levels of } \\
\text { pupils++ } \\
\text { (f) }\end{array}$ & $\begin{array}{c}\text { Cost per } \\
\text { learning } \\
\text { unit }(\mathrm{Rs} .) \\
(\mathrm{g})=\mathrm{e} / \mathrm{f}\end{array}$ \\
\hline \multicolumn{8}{|c|}{ Primary teachers } \\
\hline 2008 & 4500 & 5422 & 675 & -- & 10597 & -- & - \\
\hline $2009 *$ & 13,500 & 2970 & 2020 & 360 & 18850 & -- & - \\
\hline 2010 & 13,500 & 4725 & 2020 & 360 & 20605 & 18.7 & 1102 \\
\hline 2011 & 13,500 & 7425 & 2020 & 360 & 23305 & 12.1 & 1926 \\
\hline 2012 & 13,500 & 9450 & 2020 & 360 & 25330 & 9.1 & 2784 \\
\hline 2013 & 13,500 & 11475 & 2020 & 360 & 27355 & 11.2 & 2442 \\
\hline 2014 & 13,500 & 13500 & 2020 & 360 & 29380 & 12.1 & 2428 \\
\hline 2015 & 13,500 & 15525 & 2020 & 360 & 31405 & -- & - \\
\hline 2016 & 13,500 & 17550 & 2020 & 360 & 33430 & 10.4 & 3214 \\
\hline $2017+$ & 35,400 & 708 & 2020 & 360 & 38488 & -- & - \\
\hline \multicolumn{8}{|c|}{ Annual salary growth rate 2008 to 2017} \\
\hline \multicolumn{8}{|c|}{ Annual salary growth rate 2009 to 2016} \\
\hline \multicolumn{8}{|c|}{ Junior teachers } \\
\hline 2008 & 5500 & 6627 & 825 & --- & 12952 & -- & - \\
\hline $2009 *$ & 17140 & 3771 & 2760 & 360 & 24031 & -- & - \\
\hline 2010 & 17140 & 5999 & 2760 & 360 & 26259 & 48.2 & 545 \\
\hline 2011 & 17140 & 9427 & 2760 & 360 & 29687 & -- & - \\
\hline 2012 & 17140 & 11998 & 2760 & 360 & 32258 & 24.4 & 1322 \\
\hline 2013 & 17140 & 14569 & 2760 & 360 & 34829 & -- & -- \\
\hline 2014 & 17140 & 17140 & 2760 & 360 & 37400 & 30.5 & 1226 \\
\hline 2015 & 17140 & 19711 & 2760 & 360 & 39971 & -- & - \\
\hline 2016 & 17140 & 22282 & 2760 & 360 & 42542 & 25.5 & 1668 \\
\hline $2017+$ & 44900 & 898 & 2760 & 360 & 48918 & -- & - \\
\hline \multicolumn{8}{|c|}{ Annual salary growth rate 2008 to 2017} \\
\hline \multicolumn{4}{|c|}{ Annual salary growth rate 2009 to 2016} & $8.5 \%$ & & & \\
\hline
\end{tabular}

Source: Government Orders of the Govt. of Uttar Pradesh, various years. Note: *Sixth and Seventh Pay

Commission salaries were applied in 2009 and 2017 respectively. The Dearness Allowance (DA) is intended as inflation-proofing. It is the annual increase in Basic Pay. The cumulative DA was 22\% (in 2009), 35\% (2010), 55\% (2011), 70\% (2012), 85\% (2013), 100\% (2014), 115\% (2015), and 130\% (2016). Thus, after 2009, DA increased by 15 percentage points every year. ++ This column shows the percentage of children in class V (upper panel) and in class 8 (lower panel) who could do a three-digit by one-digit division sum. E.g., in 2010, $18.7 \%$ of class 5 pupils and $48.2 \%$ of class 8 pupils could do division (ASER, various years). 
